\title{
3 Writing, Reading, Seeing: Visuality and Contingency in the Literary Epistemology of Neoclassicism
}

Strange it is that in the most perfect sense [sc. vision] there should be so many fallacies [. . .].

Sir Thomas Browne, Christian Morals 3.15

\begin{abstract}
$\ldots \ldots \ldots \ldots$ but to nobler sights
Michael from Adam's eyes the film removed Which that false fruit that promised clearer sight Had bred: then purged with euphrasy and rue

The visual nerve, for he had much to see[.]
\end{abstract}

Paradise Lost 11.411-15

Such as were blinde, and now can see, Let 'em use this Receipt with me, 'Twill cleare the Eye, preserve the Sight, And give the understanding Light.

The Eye Cleared (1644), title page

\section{Literary Epistemology}

Histories of literature sometimes present their object as if it were the hero of a nineteenth-century bildungsroman. According to this narrative, literature has become increasingly autonomous in modernity, expanding its degrees of freedom and operating according to its own rules. Aesthetic autonomy is then seen to be fully implemented in romantic and post-romantic literature in the nineteenth century. It is doubtful whether any such teleological construct can ever be an accurate description of historical processes, particularly considering the instability of 'literature' as an object. In many respects, one might argue that complete autonomy in the arts - such as the power of literature "to say everything, in every way" (Derrida 1992, 36) - has never been achieved and remains a utopia, another "unfinished project" of modernity (Habermas 1997).

Are early modern developments merely the prehistory of an 'autonomous' literature? How are we to understand this? Traditionally, many literary histories locate decisive developments in the eighteenth century: together, these constitute the emergence of a modern framework in which literature works. There is no doubt that a number of important, or even essential, cultural achievements of the eighteenth century indeed depend on earlier developments; but I think it would be wrong simply to regard the seventeenth century as a mere way station towards something else or as 
the imperfect precursor of something less imperfect. I think the more rewarding task is to focus on seventeenth-century events in their own light, to present these processes in relation to their own 'contexture' - to view them not against the horizon of a 'no longer' or a 'not yet', but to come to understand them on their own terms.

This problem of literary historiography becomes particularly intense with regard to two major movements: empiricism and neoclassicism. These intellectual and artistic formations tend to be interpreted, retrospectively, as precursors of later developments: Enlightenment rationalism on the one hand, the aesthetic autonomy of the literary on the other. Indeed, if you look at it as a literary theory, and perhaps the first explicitly literary theory in modern Europe, neoclassicism can be read as a response to an increasing differentiation of discourses, media, and forms of communication. Such differentiation constitutes a core element of its critical reflections on the arts. Neoclassicism is not merely the result of a rediscovery or reappraisal of classical literary traditions. The 're' as 'neo': the name implies this of course, and like the term 'Renaissance', meaning 'rebirth', neoclassicism is a return to classicism, to classical traditions (Berensmeyer 2019). Among other important aspects, neoclassicism embodies a tendency to look at works of literature in isolation and to relate them to an abstract matrix of normative foundations. In other words, it seeks to read, to decipher the code of any literary work and to establish a critical discourse of value on the basis of this code: is this tragedy a good tragedy according to the norm that Aristotle has established in classical Greece? Relating the individual work to an abstract norm on the basis of a code, a kind of normative decorum, neoclassicism seeks to turn individual objects into cases that can be subsumed under general principles. In England, in distinction to French neoclassicism and in analogy to English law, distinctions between abstract norms and individual cases are handled a bit more flexibly and are seen in relation to one another as parts of an evolving continuum (see Norton 1999, 17-20).

Yet to argue for a differentiation among discourses is not at all the same as to argue for a becoming autonomous of the literary as distinct from other forms of culture, other performative dimensions of human activity and social behaviour. Normative generalisations about literature and the other arts, described by Timothy Reiss (1997) as "aesthetic rationalism", and the empirical functioning of literary and other types of communication may well overlap but they are not prima facie identical. They belong to different levels of cultural activity. To arrive at a theoretical coupling between these levels can be regarded as a particular achievement of neoclassicism under the pressure of discourses, media, and forms of communication. As we have seen in the cases of Burton and Browne, the centrifugal dynamic of knowledge and its textual organisation increasingly turns into a problem of contingency in literary communication. Neoclassicism can then be understood as a set of self-organising problem-solving strategies brought to bear on this problem.

The following chapters will circumvent the teleology of differentiation and instead trace the complex interweaving of continuities and discontinuities, focusing 
on phenomena of inertia and overlap with the aim to gain, by way of close readings and detailed analyses, a historically more saturated purchase on the literary epistemology of English neoclassicism. They will present the trajectory of neoclassicism between 1650 and 1700 in the performative contextures of English culture, i.e. in the media configurations in which texts and their reception are historically embedded. My enquiries are motivated by the following questions: what comes after the complexification, disintegration, and self-deconstruction of literary humanism that we have observed in Burton and Browne? How is contingency revalued in connection with textual communication, and how is it related to changing ideas of community, viewed alternatively as 'commonwealth' or as 'state'? Finally, where is the place of the 'individual', that celebrated Renaissance phantom, in the neoclassical order of things, and how is the relation between individualities and textualities (con-)figured in the later seventeenth century? How does modern communication emerge from premodern situations of writing and reading?

From what we know about the constitutive make-up of the 'republic of letters' in seventeenth-century England, any notion of autonomy in relation to other discourses is simply not on the map. Instead, we observe a turbulence of discourses driven by the unstable system of patronage and the underdeveloped economic resources of a literary market (Schoenfeldt 1999b). Rather than producing a homogeneous (national) literature, neoclassical criticism and creativity are marked by the co-presence of various mixed forms and, in the words of Lawrence Manley (1999, 347), "by an interorientation of urbane decora and a levelling confluence between polite and popular urban modes."

Yet, in theory at least - and, after 1688, increasingly in economic and practical terms - there is no denying that the English seventeenth century begins to conceive of a certain type of writing as distinct from other types, as separable, collectible, anthologisable (Zwicker 2003, 297-99; Benedict 1996). This kind of writing is increasingly connected to the individuality of an author, who writes for the sake of public recognition and fame (Miller 1986, Loewenstein 2002). Yet this is still not identical with the postulated autonomy of literature but rather the result of a 'conditioned co-production' (G. Spencer Brown) of literary and (other) cultural and social developments, for which the term 'neoclassicism' is a useful shorthand.

It is not only philosophical skepticism like Montaigne's or religious introspection like More's that leads to a more intense self-questioning and/as self-fashioning in the early modern period (Greenblatt 1980) but also a tendency towards individual gratification in a society of public spectacle and private capital accumulation, conspicuous consumption, and the circulating flow of commodities. Empiricism, materialism, and neoclassicism reflect the intensification of discourses. As a concrete image of this intensification, Stephen Greenblatt's famous metaphor of the "circulation of social energy" (1988) becomes a reality only from about 1630 onwards; it is more useful for Harvey (Rogers 1996, 16-27), Hobbes, and Milton than it is for Elizabethan theatre (Kroll 2002, 27-29; 2000, 104-11). Circulation, as a "new master image of the body" (Sennett 1994, 
255) after the Harveian discovery of 1628 , emphasises the analytic separation of a diffuse felt totality into its individual parts, which operate mechanically and separately, connected only by the flow of motion itself. In the flow of circulation, the individual becomes a mobile and flexible observer of self and others. When motion ceases, life ends. Apart from its political ramifications - articulated in Hobbes's Leviathan, where life is defined as "but Motion" (1.6) - the metaphor of circulation replaces a medieval configuration of fundamental sympathetic connection with one of separation, isolation, and individualisation (Sennett 1994, 255-81).

The developing book trade is merely one instance of this larger epistemic change. The marketable book, cut off from the intimate coterie setting of scribal publication, becomes a circulating mobile commodity, which gains meaning only from its circulation and its real or potential contact with individual readers or reading communities. Its value can now be measured in its saleability and expressed in the medium of money. A good example is Jacob Tonson's subscription system for Dryden's translation of Virgil, in which Dryden's work was financed by readers paying for it before it was completed. The author's name becomes a sign, a signature, a promise, a synecdoche for the work. As reputation accrues to the author from his or her work (in the sense of labour), his or her name confers coherence and authority upon the texts, gradually transforming a collection of writings into 'a work' - a work that, in the relative fixity of print, achieves an ideal unity of type removed from the contingency of any individual paper token or copy.

The functional change of literary communication in seventeenth-century England thus moves from a 'natural' or vitalistic concept of communication to a mechanistic one: from humanist metaphors of digestion, assimilation, and alchemical transformation (still evident in Burton and in Milton's Areopagitica) to a rather more technical vocabulary of machine interaction, which invokes procedures of distinction, coupling/ uncoupling, and the metaphor of 'imprinting' as the fundamental mode of 'literate experience' (Barnaby and Schnell 2002). Prior to this epistemic change, whose origins probably lie in the second half of the fifteenth century, it is difficult to form an abstract concept of communication or a semiotic concept of signification.

In this context, it becomes compelling to argue that, in the words of Barnaby and Schnell (2002, 197), the "novel conceptualization of experimental discourse" in the seventeenth century "as an unending cooperative and communal exchange of ideas" - in other words, as a form of social circulation - ought to be regarded as the paradigmatic epistemic underpinning of neoclassical literary culture; not because it supposedly provides access to some objective reality but because it acknowledges the difficulty of attaining any certain knowledge about its objects of enquiry and develops discursive structures and procedures of coping with uncertainty. Knowledge must be mediated in language, but language is seen to be an opaque medium. For this reason, the contingent fit of language and truth must be made amenable to public negotiation and accountability, establishing a non-deterministic rhetoric of contingency that would come to dominate the discourse of neoclassicism (Kroll 1991, 52, 77, 85). 
Contingency and difference, not autonomy and homogeneity, define the field of discourse. Nevertheless, there is in some areas a tendency to homogenise specific differences, for instance in the concept of the nation and its association with literary phenomena like the English 'mixed mode' (Docherty 1999); but even this should not be confused with an increasing autonomy of literature.

This discourse, then, involves much more than only literary theory. It dominates political thought and natural philosophy as well as debates about religion in the later seventeenth century and beyond. Hence, to regard it merely as a first step towards a modern and autonomous literary system would be to neglect, wilfully and prematurely, the actual cultural achievement and impact of English neoclassicism. Rather than arguing for their isolation, neoclassicism aims to observe the circulation among different levels and elements of the social, which it figures as mobile, dynamic and heterogeneous. Its modernity, in this view, resides precisely in its focus on the connectivity between individual elements and larger configurations, between parts and wholes, between bodies natural and the body politic. Such connections can no longer be taken for granted in the later seventeenth century: the old analogy between micro- and macrocosm has lost its binding force. It is replaced by the semantics of mechanical circulation in physiology as well as in political and economic thought (Bylebyl 1979; Rogers 1996, 16-27; Kroll 2000, 104-5).

The distinction between literary texts and other forms of discourse, the relation of the individual literary work to the general rules of art, all this is vividly discussed by Dryden in the Essay of Dramatick Poesie, a text that is often metonymically equated with English neoclassicism in a narrow, literary-critical sense. In writing about literature, seventeenth-century poets and critics are as far away from romantic assertions of genius or modernist assertions of impersonality as it is possible to imagine. Their concern is with the pragmatic embedding of literary objects in the real world instead of an ahistorical universality. For Davenant, writing in 1650, the connection between heroic poetry and its social setting is a case in point. Poetry, for Davenant, is a repertoire of cultural values towards which specific elements of the commonwealth (the army, the law, the church) stand in contingent relations. Poetry can then serve as a common unifying bond among these elements, which are in dire need of such a bond because of perpetual conflicts between them - a lesson of the Civil War. But this repertoire of values is not eternal and unchanging; rather, it consists of a selection of moral precepts, deemed useful for maintaining public order, which have to be changed and adapted if poetry is to remain useful in this way. Poetry - or fiction more generally - around 1650 thus does not exist in a space beyond society but is inextricably connected to it. Its function is ultimately understood as rhetorical, hortatory, performative - not as aesthetic, merely entertaining, or expressive of a 'higher' truth. Even though writers and critics begin to observe the literary in isolation from other discourses, it remains firmly connected to social and political concerns. In most cases, then, even theoretical arguments about literature in the seventeenth century have political implications. 
Both empiricism and neoclassicism enjoin a certain perspective towards literary communication, a perspective that, without being simply utilitarian or ideological, situates literary activities in a network of mobile relations, in a framework of pragmatic exchanges that does not exclude what we would call ideological determinations. As a scientific attitude or, more precisely, a historical style of thought and representation, the "analytico-referential discourse" (Reiss 1982a) of empiricism and neoclassicism systematically introduces the contingency of experiences and observations into a generalised, normative order of communication. In his study on the connection between science and gentlemanly conduct in seventeenth-century England, Steven Shapin elucidates the moral bond of trust and belief that determines assent or denial of claims to factual knowledge; he describes the epistemological change that occurs in the seventeenth century as an "inversion of authority relations between word and world” (1994, 198). Whereas, in the Renaissance, personal testimony and authority were primary factors in determining the legitimacy of a new observation, which had to fit into "existing plausibility schemes", it is now a matter of adapting or even rejecting those schemes "because they conflicted with legitimate new experience" (198). The probable thus comes to be defined no longer as that whose truth is "warranted by authoritative and respected sources (as in 'probity')" but as a gauge for the remaining uncertainty of a hypothesis in relation to empirical evidence: "a quality of uncertain knowledge apportioned to the evidence available” (198) - which is the modern definition of probability (Hacking 1975, Shapin and Schaffer 1985).

It seems paradoxical that the modern concepts of science and the growth of knowledge should contain a greater degree of uncertainty than during earlier periods, which relied to a greater extent on derived authority to distinguish between true and false knowledge. In the seventeenth century, this uncertainty can still be cushioned in the social conventions of gentlemanly conduct. The semantics of the gentleman-scientist functions as a link between the older form of authority and the new ideals of scientific objectivity. Yet the evolution of science towards more and more complex and compartmentalised disciplines requires equally more complex modes of sorting true and false knowledge than mere appeals to morality are capable of supplying. Trust is no longer invested in individual authorities but in generalised structures or institutions: particular places of research like the laboratory or the dissecting room, associations of scientists like the Royal Society, certain organs of publication, etc. The stylistic norms of scientific communication are adapted to this shift. In the process, experiential and cognitive styles of abstraction and concreteness drift further apart (Claessens 1993).

The linked notions of 'experiential style' and 'cognitive style' (Schütz and Luckmann 1973) provide an important connection between a social history of knowledge and the history of ideas or mentalities - a connection that becomes more substantial if we relate the modern idea of science to the modern concept of reality as described by Blumenberg in terms of an 'open context' (1979). The discourse of empiricism is one instance in which this modern concept can be exemplified, in analogy to my understanding of neoclassicism and the epistemological 
foundations of seventeenth-century literary culture. Its horizon is open inasmuch as it is constantly modified by new observations and discoveries, so that its participants have to learn to expect the unexpected and to resist premature conclusions. For individuals, the farther-reaching consequences of this openness need not have immediate consequences for either their experiential or cognitive styles and will probably be eclipsed in the pursuit of everyday routines. But a reflection on the increasing production of knowledge and what it entails - the continual modification of reality as it is experienced - will not only result in greater individual uncertainty but will also increase demand for institutional consequences to absorb and ritualise this uncertainty. Now one becomes aware of the fact that the increase of knowledge is inevitably connected to an increase of ignorance, of blank spaces and uncertainty. As knowledge expands, so does the horizon of the unknown. We have already seen this dialectic at work in Burton and Browne. In the early modern age, the horizon of possible knowledge - including the number of potential follow-up questions expands ad infinitum. "All sciences", writes Pascal, "are infinite in the expansion of their problems” (Pascal 1963, 526, my translation; cf. Berensmeyer 2003).

Neoclassicism is concerned with developing strategies to cope with the epistemic, social and political contingency that arises from this radical expansion of the horizon in modernity. It is thus closely linked to changes in the episteme of seventeenth- and eighteenth-century European culture, particularly the rise of "analytico-referential discourse” (Reiss 1999 and Reiss 1997, 135-200). These changes face the problem of contingency by developing techniques and procedures of safeguarding legitimate knowledge by means of method, rule-governed observation, and probable inference. They further involve a new understanding of language and rhetoric as a medium of communication for the public exchange of ideas and opinions. In this epistemic change, traditional ideals of stability, coherence, and certainty give way to a dynamic system of values expressed in a conceptual rhetoric of mobility, circulation, contingency, and probability.

If neoclassicism is identified as a strategy for dealing with contingency, also in the field of literature, one has to specify the epistemological preconditions of this strategy, the foundations on which it operates, and finally to answer the question how it establishes the functional boundaries of literary communication to other media, other performative levels of culture. With this guiding perspective in mind, the following readings focus on the embattled, polemic, and polemogenic relation between literary and visual forms of communication, between modes of visual immediacy and forms of rhetoric mediated through language. As can be seen in the writings of Milton, Hobbes, Davenant, and Cavendish, this relation is usually fraught with epistemological and political implications as well as problems of aesthetics and poetics; these problems and implications cannot easily be kept apart. The readings that follow in this chapter are all concerned with the potential impact of literary in comparison with other, predominantly visual, modes of communication. They also 
involve the question how seventeenth-century writers imagine the act of reading and how they adapt their literary strategies and tactics accordingly.

Against the background of the correlation between empiricist theories of sense perception and media performance, I shall try to demonstrate how literature and its neoclassical reflection compete with other media. For this purpose, I am first going to analyse functions of image and text in Milton and Hobbes, before turning to Hobbes's theoretical grasp of literary communication, especially the epic poem. The focus here will be on Hobbes's collaboration with Davenant, which should enjoy pride of place in any history of neoclassical, materialist poetics. Beside Davenant's Preface to Gondibert, the political dimensions included in neoclassical media and genre theory are finally illustrated by a reading of Margaret Cavendish's The Blazing World and its explicit convergence of discursive and political hierarchy.

\section{"Not Truth, But Image, Maketh Passion": Optics and the Force of Reading in Milton and Hobbes}

Their vast differences notwithstanding, Milton and Hobbes share a sharp awareness of the epistemic and political impact of images. They serve as ideal case studies for the correlation between seventeenth-century theories of (predominantly visual) sense perception and literary or media practices; in both writers, the convergence of empiricism and literary culture is also eminently political.

In 1649, a book is published to coincide with the trial and execution of Charles I, purporting to present an authentic and true image, even a religious 'icon' of this king. The frontispiece to Eikon Basilike, by William Marshall (Fig. 2), emphasises this idealising gesture in its presentation of Charles as a saintly martyr who has put off his worldy crown, holding a crown of thorns in his right hand and looking upwards to behold a luminous crown in heaven. A beam of light connects this heavenly crown with the eyes of the kneeling monarch.

As Jim Daems and Holly Faith Nelson remind us, Eikon Basilike - purportedly written by Charles I himself - becomes an instant bestseller in England and across Europe, with a total of sixty editions in 1649 alone $(2006,14)$. As a piece of PR intended to restore the king's reputation, the book was immensely successful. The impact of Milton's Eikonoklastes (1649), his printed rebuttal to Eikon Basilike's royalist propaganda, was negligible in comparison. Milton's goal in this text is to deconstruct the king's iconic image, to be a 'breaker of images' or iconoclast, to destroy the "superstitious" idol by the power of rational argument, and to replace the king's image of a martyr with the image of a tyrant (Loewenstein 1990, 51-73). Milton engages a republican rhetoric of words (which he equates with rationality and analysis, as he does in Areopagitica) against the royalist rhetoric of images, which he denounces as "quaint Emblems and devices" (Milton 1957a, 343). He emphasises the theatricality, the illusory and stagey quality of these images, i.e. their 


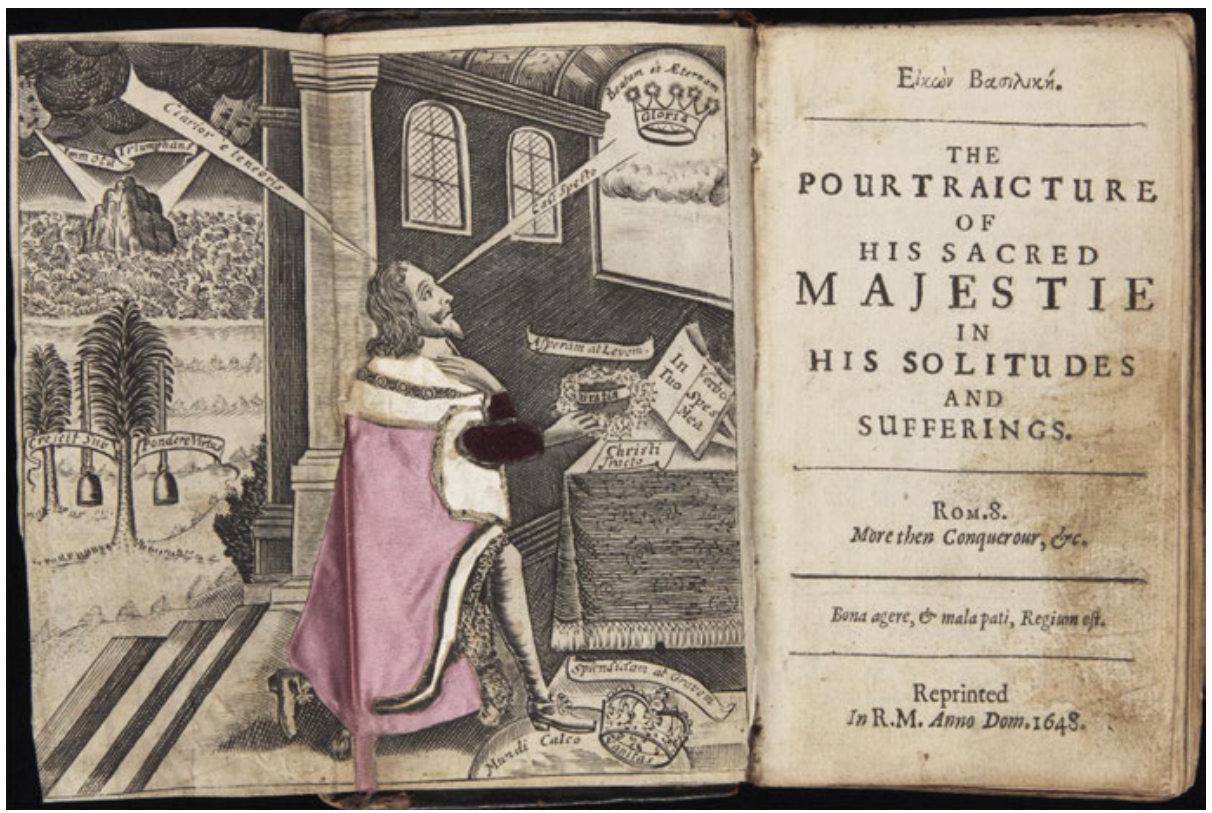

Fig. 2: Frontispiece by William Marshall and title page of Eikon Basilike. Beinecke Rare Book \& Manuscript Library, Yale University. Wikimedia Commons.

lack of truthfulness, writing that they are "begg'd from the old Pageantry of some Twelf-nights entertainment at Whitehall" (343). This comparison also underlines the aristocratic distance of the royal image from the common people who are the target readers of Eikon Basilike, the book and its frontispiece. Against the visually mediated, (crypto-)Catholic ideology and eidology of tyranny, the republican Milton pits "the old English fortitude and love of Freedom" (344). For Milton, "the People" are not naturally inclined to barbarism and do not need a strong arm to control them; instead, their "low dejection and debasement of mind" is a product of the ideology and propaganda of "the Prelats" and "the factious inclination of most men divided from the public by several ends and humors of thir own" (344).

Milton, like Hobbes, has to face the problem of the multitude, of social unity. The staging of the royal image simply takes this unity for granted, or ignores its absence; Milton's words, however, have to develop a theoretical construct and a rhetorical strategy for its communication. Images are suggestive rather than analytic, and even though the Marshall 'icon' also requires interpretation, its effect is more immediate in addressing an audience, including the illiterate. Hobbes will later find a visual analogue to his theory of the state in the frontispiece to Leviathan. Milton the iconoclast has to expend quite a bit of rhetorical labour on constructing an implied audience, a public that can sustain the division between those "who adhere to wisdom and to truth" and "the vulgar sort", who are irredeemably lost to the anti-republican forces of 
superstitious zealotry and the magic of images (348). His syntax aches under the burden of semantic strain, having to keep these disparate forces together and to avoid the impression that even his own side, the rational and righteous republicans who wish to stem the "rage and torrent" of unreason, could only be "a sect or faction":

Certainly, if ignorance and perversness will needs be national and universal, then they who adhere to wisdom and to truth, are not therfore to be blam'd, for beeing so few as to seem a sect or faction. But in my opinion it goes not ill with that people where these vertues grow so numerous and well joyn'd together as to resist and make head against the rage and torrent of that boistrous folly and superstition that possesses and hurries on the vulgar sort.

The passage remains somewhat nebulous concerning the question who is pushing and who is pulling whom, and to what end precisely. Milton's language betrays an anxiety about the persuasive influence of images on "the vulgar sort" when he writes that image-based royalist propaganda may not convince "any wise Man" or “any knowing Christian” but may well

catch the worthles approbation of an inconstant, irrational, and Image-doting rabble; that like a credulous and hapless herd, begott'n to servility, and inchanted with these popular institutes of Tyranny, subscrib'd with a new device of the Kings Picture at his praiers, hold out both thir eares with such delight and ravishment to be stigmatiz'd and board through in witness of thir own voluntary and beloved baseness. The rest, whom perhaps ignorance without malice, or some error, less then fatal, hath for the time misledd, on this side Sorcery or obduration, may find the grace and good guidance to bethink themselves, and recover.

(601, my italics)

The hope expressed in the last sentence also betrays some degree of uncertainty about the possibility of converting, by rational argument and the power of words, those who have been "misledd" by images. But if the approval of the "rabble" is "worthles", why bother? The difficulty Milton has with the irrational power of images in relation to rational language can also be presented in terms of a problem with the political status of the London crowds, the largely illiterate lower classes or "vulgar sort", whose attention is more easily reached by visual than verbal means (Harris 1987). How can rational communication address these inferior parts of society which, even though they are intellectually "worthles" and - a striking phrase for a republican - "begott'n to servility", are yet of crucial importance to public stability and peace? Are images a stronger means to "catch the [. . .] approbation of [the] rabble" than spoken or printed words? The 'Catholic' image of the king on the frontispiece of Eikon Basilike seems to know better than Milton's Protestant faith in words: although the open book on the king's altar proclaims "In verbo tuo spes mea" - "in your word I place my hope" - the king's eyes are looking away from the book; they are turned up towards the heavens for a more immediate visual contact with the beyond than reading can provide. Even this image itself does not seem to believe in the word as much as in seeing the light visually, in a direct way.

The conflict between image and word becomes more complex as soon as words are printed rather than heard, having to enter a reader's mind by the same channel, 
as it were, as do images, through the sense of vision. The widespread distrust regarding the deceptive character of writing is only partially alleviated by making written language as much as possible resemble spoken language, though this effect can be highly artificial, as in the case of Milton's Areopagitica, written as a simulated speech for the medium of print. ${ }^{43}$ With increasing intensity, Milton's texts turn towards oral and aural effects that circumvent, perhaps even contravene the visual impression of a page. The syntax and prosody of Paradise Lost are a case in point: Milton frequently uses enjambment, continuing sentences and phrases across the line breaks, thus breaking up the visual neatness of verse with the aural counterpoint of different rhythmic sequences. He relies on the reader's (as well as his own) ability to listen rather than visualise, to intuit and understand rather than to imagine and admire. The aim is to leave behind a passive, identificatory, and "image-doting" (if you like, satanic) mode of reading for a critical, confrontational, and self-transformative attitude. Paradise Lost and Paradise Regained are a 'training programme' teaching its readers how to approach visuality and how to interpret images and signs. This becomes particularly clear in the last two books of Paradise Lost, in which the Archangel Michael provides Adam - as a stand-in for the (male) reader - not only with privileged insight into salvation history but also with a crash course in techniques of reading and interpretation. If the intention of Paradise Lost is less to picture the Christian myth in an imaginative way than to achieve an intellectual, reflexive distance from myth (as well as from Milton's epic precursors), this may well be aided by Milton's preference of orality/aurality over visual 'effects'. Paradise Lost teaches its readers to question, to suspend, even to deny their power to visualise what is presented, in order to arrive at a 'better', more rational understanding of the unbridgeable abyss between deity and humanity. When Raphael describes the "war in heaven" using Homeric language but including modern artillery (for which Milton was ridiculed by Voltaire), this happens in full awareness of the unpresentable nature of heavenly events and according to the Pauline principle of accommodation. Working by means of verbal sound (Leonard 2001), the poem leads the reader into a confrontation with the paradoxes of vision, blindness, and non-visual insight as well as with the difficulties of language, meaning, and poetic form encountered by its epic speaker in his project of "justify[ing] the ways of God to men" (Milton 1998, 1.26). The difficulties are heaped up, above all, in the successive proems that, after a very strong start, turn more and more hesitant and doubtful.

Milton's own blindness may have been an important factor in foregrounding these paradoxes of vision and insight, but it is not essential to his argument. Rather, his literary enterprise takes part in an epistemological denigration of the visual that is characteristic of much of early modern philosophy and science, including techniques of

43 On early modern reading, more generally, as both aural and visual, see Brayman Hackel 2005, 43-52. 
religious meditation. As in arithmetic and geometry, which function as early modern paradigms for the scientific ethos of abstraction, universal validity and compelling persuasiveness, real objects that appear to the eye with all their uncertainties, warts and all, are reduced to and replaced by ideal, rational, and certain constructions. In this process, the blind man, who cannot be deceived by the visual illusions of the phenomenal world, becomes the guarantor of "solid and true" knowledge, of what Descartes calls "distinct and clear intuition" $(1953,37,67)$. In the Second Defense of the English People of 1654, it is this very argument that Milton uses against his detractors, who interpret his blindness as divine retribution. Addressing his opponent Alexander More, he writes:

as to my blindness, I would rather have mine, if it be necessary, than either theirs, More, or yours. Your blindness, deeply implanted in the inmost faculties, obscures the mind, so that you may see nothing whole or real. Mine, which you make a reproach, merely deprives things of color and superficial appearance. What is true and essential in them is not lost to my intellectual vision.

(Trans. Helen North, Milton 1966, 589)

In the phrases that follow, "darkness" and "light" are transvaluated, as they are in some instances in Paradise Lost, to transform blindness from an "infirmity" to a perfection that makes possible the "keen [. . . ] vision" of "an inner and far more enduring light” (590). But Milton's proems in Paradise Lost, those passages where he introduces the topic of his speaker's blindness, are much more complex than his counter-polemic in the Defensio Secunda. At first, they appear to emphasise the privileged reality of a 'higher' intellectual and theological vision in contrast to the unreliability of mere physical sight in the same way as Milton's earlier prose text had done. Interpreted in this manner, the reader would be invited to share or to imitate the speaker's privileged inner (blind) vision, whereas Satan (and, to a certain extent, both Adam and Eve) would be exposed as bad readers who are duped by the deceptive glamour of external appearances, either wilfully ignoring (in the case of Satan) or sadly misunderstanding (in the case of humankind) the more profound levels of divine reality.

Yet, in contrast to a rationalist or Cartesian belief in "distinct and clear intuition" or a mystical assertion of noetic superiority, the invocatory passages in Paradise Lost turn the trope of blindness into a dramatic assertion of trial, suffering, and radical uncertainty. Read superficially, they might appear as merely conventional elements of epic poetry, or - worse - poetic restatements of Milton's earlier polemic, asserting the epistemic and prophetic advantages of blindness:

$\ldots \ldots \ldots$ what in me is dark

Illumine, what is low raise and support;

That to the height of this great argument

I may assert the eternal providence

And justify the ways of God to men.

(Milton 1998, 1.22-26) 
So much the rather thou celestial light

Shine inward, and the mind through all her powers

Irradiate, there plant eyes, all mist from thence

Purge and disperse, that I may see and tell

Of things invisible to mortal sight.

Yet, in the context of the poem, these statements, injunctive as they are, never meet with any confirmation from the instance they invoke. The speaker even seems to invite a sceptical response at the beginning of Book 9, where he voices his doubts about the appropriateness of heroic epic as a form for his work. These doubts may be doubly ironic, evoking a disparity between Milton and his speaker:

......... unless an age too late, or cold

Climate, or years damp my intended wing

Depressed, and much they may, if all be mine,

Not hers who brings it nightly to my ear.

(9.44-47)

Thus the speaker's blindness, rather than betokening either a condign punishment of sin or a privileged mystical contact with the divine, accentuates the contingency of human affliction and the inscrutable hiddenness of God - a cornerstone of Protestant theology, including Milton's (Silver 2001, 153-207). In Victoria Silver's analysis, Milton's speaker's project of justification is "revisionary" rather than merely visionary (2001, 207). As Silver argues, the epic invocation of the heavenly Muse is transformed, in Paradise Lost, into a dramatic enactment of lost assurance, a request rather than a ratification of prophetic vision $(196,199)$. Indeed, for the Protestant Milton "to presume the efficacy of invocation" would be "to commit idolatry of the same order as the Catholic mass" (202). Satanic and Adamic idolatry or "visualism" in Paradise Lost implies a negation of contingency and a relinquishing of "subjectivity - mind, volition, individuality - to the delusion of absolute and self-evident meaning" (338). Note that the nightly visitations experienced by the speaker are aural, not visual in nature ("to my ear").

Milton's project of justification is developed in the poem as a narrative of spiritual exertion, as an unceasing process of learning and searching that is experienced as painful because it can never arrive at the certainty of consummation. As Silver explains, "[t]he speaker too has only the ordinary consolation of his own perseverance in telling the story, with the result that speech here is the locus of revelation in a transfigured but not a supernatural sense" $(2001,195)$. The poem does not resolve the speaker's dilemma; his blindness may not be divinely ordained, but neither is it the certain sign of a privileged knowledge of the divine. Faith and hope can thus only be based on the word of revelation, as the frontispiece to Eikon Basilike also argues, but never in the self-assured and complacent way in which the royal martyr is depicted to be in contact with the deity, his line of sight directly corresponding to God's and thereby 
suggesting a continuity between the worldly and the divine. Rather, the text of Paradise Lost reproduces a Lutheran understanding of Scripture as an opponent to the reader; it resists assimilation by a reader who comes to it looking for mere information rather than self-transformation. The poem implicates the reader in the speaker's (and Milton's) labour of understanding, of justifying. It argues, as Milton's prose had done before, for the painful but ultimately salvific labour of deciphering and perfecting the always incomplete text of truth against the idolatrous gratification of curiosity in "distinct and clear" images.

But this complexity of unfinished and heterogeneous truth, which necessitates the exacting labours of interpretation as 'right reading', is extremely difficult to transform into a new political order, as Milton also had to realise and as we can see in the complexity of his late works, including Paradise Lost. In England, one of the greatest problems of the new republican state turns out to be its inability to find convincing images for its public representation. After the statue of the king at the Royal Exchange has been beheaded and removed, it is replaced by an empty, imageless space with the inscription "Exit Tyrannus regum Ultimus, anno primo restitutae libertatis Angliae 1648". ${ }^{44}$ No image but a text, and in Latin too - this iconoclastic extreme probably did little to attract the masses and secure their "approbation". The absence of the royal body (Kantorowicz 1957) opens up an imageless vacuum that is abhorred by many as unnatural and deeply disconcerting. The new state's obvious problems with political iconography grows more severe during the Protectorate, as its attitude towards public display grows more ambiguous. An uncanny effect is produced, for example, by an engraving showing Cromwell on horseback, which, apart from the face, is virtually identical to an engraving of Charles I (both by Peter Lombart after Anthony van Dyck; reproduced in Schama 2001, n. p.). Cromwell, who keeps refusing all offers of a crown, is yet given an elaborate regal funeral after his death in 1658, including a traditional waxen effigy with royal insignia (Norbrook 1999, 379-82).

It is likely that pamphlets and chapbooks, which largely rely on visual cues for their propagandistic purposes, are more successful in convincing the "vulgar" than Milton's complex rhetoric. If, for Sir Thomas Browne, even the Scriptures have to use a technique of accommodation to aid readers in understanding otherwise "unspeakable mysteries" (2012, 51, Religio 1.45), then secular authorities like the English Republic can hardly be expected to trust their "vulgar" subjects with greater intellectual powers. In fact, texts and images, reading and visuality are connected in early modernity on a yet deeper level, independent of social distinctions like that between the 'vulgar' and the 'person of quality'. This concerns the physiological process of reading itself. Here, there is no strict distinction between the processing of images and that of texts - both

44 "Exit the tyrant, the last of kings, in the first year of England's restored liberty, 1648[/9]." The date is given in old style, according to current practice. Cit. in Norbrook 1999, 199. On the visual poverty of Commonwealth and Protectorate, see also Sharpe 2000b, 223-65. 
converge in visual perception and then work on human passions. The widespread "discredit surrounding printed books" (Johns 1998, 423) is not only due to the usual concerns about eloquence and rhetoric but is reinforced by the visual nature of reading. The conflict between sight and hearing in Milton also stems from the cultural predominance of the visual sense, above all in materialist philosophy. For Hobbes, vision is "the noblest of [th]e senses" (1646, fol. $2^{\mathrm{v}}$ ), and his theory of sense perception is based on detailed studies and experiments in the field of optics. Hobbes's and Descartes's work on optics advance the scientific exploration of light and vision in mechanistic and mediumistic terms. What Hobbes and Descartes share, in the words of Jan Prins (1996, 138), is an understanding of "vision [as] an acquired capacity based on complicated, unconscious inferences, presumably based on comparing experiences through trial and error. In a sense, both Hobbes and Descartes consider the relation between vision and the visible as the product of an illusion" - as, we might add, does Milton. Because Hobbes believes all natural phenomena to be reducible to local motion of material bodies, he thinks of light as action at a distance, propagated to the eye through a medium. Visual perception is produced by the pressure (motion) of the agent, passed on by the medium to the eye, which passively receives the motion and communicates it via the optic nerve into "the brain, or spirits, or some internal substance in the head" (Hobbes 1994, 25; EL 1.2.7). Vision is a mechanical response to a stimulus. As Hobbes explains in the Elements of Law (1.2.8), "the interior coat of the eye is nothing else but a piece of the optic nerve, and therefore the motion is still continued thereby into the brain, and by resistance or reaction of the brain, is also a rebound in the optic nerve again, which we not conceiving as motion or rebound from within, think it is without, and call it light” (1994, 25).

According to Hobbes's Tractatus Opticus I (c. 1640), "all action is local motion in the agent, as all passion is local motion in the patient", ${ }^{45}$ so that vision is a "passion" (passio) in the sensing subject. Agents have a power to move, while patients have an inherent power to be moved. These ideas underpin Hobbes's psychology and, ultimately, his social theory as well. In the mechanistic understanding, psychological powers, like sense, understanding, and appetite, operate as properties of the 'animal spirits', which are conceptualised as imperceptible but nonetheless material substances that circulate through the body, connect its several parts, and direct all operations of the organism by propagating motion from one part of the body to another. These spirits are passive; they can function as agents only when they have been set in motion by something else, when they have received a mechanical stimulus.

45 "Omnis actio est motus localis in agente, sicut et omnis passio est motus localis in patiente: Agentis nomine intelligo corpus, cujus motu producitur effectus in alio corpore; patientis, in quo motus aliquis ab alio corpore generatur" (Hobbes 1839-1845a, 5: 217). 
In Hobbes's epistemology, what we perceive as reality is comprised by the internal appearances of the objects beyond us, caused by motion, so that "we compute nothing but our own phantasms" (1839-1845b, 1: 92). ${ }^{46}$ The ontological status of the outside world can only be inferred from the fact that, because "there is nothing whereof there is not some cause" $(E L 1.6 .9 ; 1994,42)$, there must be something 'out there' that acts on the senses and the mind: "The things that really are in the world without us, are those motions by which these seemings are caused" (1.2.10; 1994, 26). The motions of the visual lines or optical axes are a controlled movement determined by attention and interest, "based on the motions around the heart" (Prins 1996, 143). On this level, seeing and reading are analogous processes. Silent reading is a special case of visual sense perception (Elsky 1989, 128; Saenger 1997, Olson 1994). Widespread and influential as mechanist epistemology is in seventeenth-century learned circles, it can help us understand the political distrust of the spread of printed texts and the increase of literacy. With Hobbes (and, below, Davenant) we also approach a contemporary conception of how literature works and how the split between word and image might be overcome.

Adrian Johns has succinctly summed up "what early modern men and women thought actually happened when they read" as follows (1998, 442; cf. Johns 1996): "They saw letters on a page through eyes that resembled the device known as the camera obscura, which conveyed images, through the body's animal spirits, onto the brain's sensus communis. There imaginative and perceptual images combined, and animal spirits mingled and departed to drive the body's responses to both." Reading thus has an effect on mind and body alike, affecting the interface between them (for Hobbes, there is no Cartesian separation here, because the heart and the brain are sense organs). In weaker minds, reading can trigger potentially dangerous mental and physical responses through its impact on the passions. This term 'passion' is somewhat equivocal in Hobbes, and its meanings can sometimes overlap in an interesting way. In some instances, where the word is used in a more abstract sense, it denotes the passive quality of a patient as opposed to an agent. More frequently, it is used in close proximity to the term "affections", both being concrete acts of "that power of the mind which we call motive" in contrast to "power cognitive" or "conceptive" (EL 1.6.9; Hobbes 1994, 43). According to the expectation of pleasure or pain, the motion produced by the "power conceptive" is communicated, via the mind's "power motive" ("that by which the mind giveth animal motion to that body wherein it existeth") to the "heart," stimulating or inhibiting ('helping' or 'hindering') "the vital motion" of the body $(1.7 .1 ; 43)$. Thus reason and passion - "the principal parts of our nature" $(1994,19)$ - are not opposing forces (head vs. heart or mind vs. body) but belong to a continuum of motions in different physical locations of the body,

46 De corpore 1: 2.7.1: "ne [. . .] quidem [. . .] aliud computamus, quam phantasmata nostra" (Hobbes 1839-1845a, 1: 82). 
"within the head" and "about the heart" $\left(1.7 .1\right.$; 43). ${ }^{47}$ The lack of precision in this physiological description is probably intentional, as it emphasises the ubiquity and continuity of "internal [. . .] animal motion" (1.7.2; 43-44) in Hobbes's anthropology, which is not based on a clean Cartesian separation between res cogitans and res extensa. Pleasure and pain are interpreted as internal motions of attraction and repulsion, which are "the first unperceived beginnings of our actions" $(1.12 .1 ; 70)$. In the transition from internal and unperceived to external and perceptible motion, the passions play the role of a catalyst, intensifying or inhibiting: "appetite" and "aversion" or (prospectively, as the expectation of future displeasure) "fear".

In the rather broad and terminologically imprecise concept of passion, Hobbes appears to have found a way of preserving a porous boundary between emotional and rational desires (such as the long-term desire for self-preservation). The lengthy enumerations of individual passions in the Elements of Law (1.9) and Leviathan (1.6) list what modern psychologists would probably describe as emotionally coloured mental states, from love and hatred to curiosity and admiration. For Hobbes, the rational and the emotional are not mutually exclusive human dimensions but form a continuum on a scale ranging from 'reason' to 'madness', from control of the passions to their uncontrolled excess (Leviathan 1.8). Thus emotional desires are not in themselves irrational, but they can become irrational when they conflict with what is perceived as rational.

In their influence on men's actions, the passions are of decisive importance, as the title to chapter 1.12 of the Elements makes unmistakably clear: "HOW BY DELIBERATION FROM PASSIONS PROCEED MEN'S ACTIONS”. Here is the crucial link between anthropology, epistemology, and political theory. In the Leviathan, Hobbes confirms the optical foundations of his theory of perception by comparing the passions to magnifying lenses or telescopes ( $L$ 2.18; 1996, 129): "For all men are by nature provided of notable multiplying glasses, (that is their Passions and Selfe-love,) through which, every little payment appeareth a great grievance." Looked at through the lens of the passions, the individual's public duties appear exaggerated out of all proportion in relation to self-interest. For Hobbes, what people lack but need are the corrective "prospective glasses, (namely Morall and Civill Science,)" which will lead them towards a recognition of the superior value of the common interest (ibid.). ${ }^{48}$

47 From 1643 onwards, Hobbes explicitly locates the central organ of sensory perception, where 'phantasms' are processed, in the heart rather than the brain. Prins $(1996,141)$ cites a passage from Hobbes's critique of De Mundo by Thomas White (1643) as the turning point. The act of vision is then "defined as an outwardly directed reaction evoked in the heart by the action of a luminous or illuminated body" (142).

48 On the optical qualities of prospective glasses, which combined fragments of images into one new image, as a metaphor of higher-level cognition in Hobbes (and an analogy to the functioning of the Leviathan), see Bredekamp 1999, 83-94; cf. Gilman 1978. 
The passions are perceptual filters that determine the interpretation of the 'phantasms' of perception. The term that is sometimes used for these filters is again an optical one: 'colour', a term from classical rhetoric that denotes a manipulative twist or spin (Bacon 1996, Hobbes 1986; Skinner 1996, 195-98). By influencing these filters, through language or by other (e.g. visual) means, it is possible to influence men's actions. Passions not only colour but distort people's view of reality, including their political situation. This anthropological predicament can be exploited for political (ideological) purposes. Another chapter heading in the Elements of Law is "HOW BY LANGUAGE MEN WORK UPON EACH OTHER'S MINDS”. Hobbes develops an early form of speech act theory, in which language is not merely a tool to describe the world but in which it also has pragmatic and performative functions (cf. Leviathan 1.14 on promises; see Brekle 1975, 295; Sorell 1996, 163). ${ }^{49}$ Language can excite or calm the passions; it can be used to communicate a speaker's opinions and attitudes, or to influence the opinions and actions of others. In this respect, it carries the "tincture of our different passions" ( $L$ 1.4; Hobbes 1996, 31).

And therefore in reasoning, a man must take heed of words; which [. . .] have a signification also of the nature, disposition, and interest of the speaker; such as are the names of Vertues, and Vices; For one man calleth Wisdome, what another calleth feare; and one cruelty, what another justice [. . .]. And therefore such names can never be true grounds of any ratiocination. (Ibid.)

Language, in this view, is what makes science possible, but it can also generate misunderstanding and confusion. Hobbes describes its negative consequences for social life in more detail in De homine 10.3 (1658). In distinction to animals, only human beings "can devise errors and pass them on for the use of others" (Hobbes 1991, 183).

Man if it please him (and it will please him as often as it seems to advance his plans) can teach what he knows to be false from works that he hath inherited; that is, he can lie and render the minds of men hostile to the conditions of society and peace; something that cannot happen in the societies of other animals, since they judge what things are good and bad for them by their senses, not on the basis of the complaints of others, the causes whereof, unless they be seen, they cannot understand. Moreover, it sometimes happens to those that listen to philosophers and Schoolmen that listening becomes a habit, and the words that they hear they accept rashly, even though no sense can be had from them (for such are the kind of words invented by teachers to hide their own ignorance), and they use them, believing that they are saying something when they say nothing. Finally, on account of the ease of speech, the man who truly doth not think, speaks; and what he says, he believes to be true, and he can deceive himself; a beast cannot deceive himself. Therefore by oratio man is not made better, but only given greater possibilities. (Ibid.)

In this context, the two meanings of 'passion' overlap: speech is an agent that "works upon" the mind as a passive recipient; more precisely, speech acts upon the

49 Hobbes is not the only author to develop a performative understanding of language in early modernity; he summarises skeptic, Baconian, and Grotian attitudes towards language. See, e.g., Grotius 1977, 1: 292-93 on promises. 
passions as catalysts of the internal motions ("endeavours") by which conceptions are translated into actions. We can infer that the spread of printed pamphlets, communication at a distance, only aggravates the potential abuse of speech by providing even "greater possibilities" than verbal interaction.

In a public sphere swayed by rhetoric, the passions of pity and indignation "are most easily raised and increased by eloquence", which can for instance "magnify" a person's “success” (EL 1.9.10-11; Hobbes 1994, 53-54). ${ }^{50}$ Weak or uneducated minds, who have difficulties controlling their passions - because, to stay with the optical metaphor propounded in Leviathan, they can see only fragments of reality magnified through the distorting lenses of passion, unable to assemble the complete picture out of its dispersed elements - are a sitting target for the lures of rhetoric and therefore need special attention, education and control. In a Miltonic gesture at the interpretative and educational authority of a minor segment of the polity, Hobbes notes in the Elements of Law (1.13.3) that "commonly truth is on the side of the few, rather than of the multitude" $(1994,74)$.

If it is the disagreement of private judgements that creates moral and social conflict, Hobbes suggests politics as its solution, understood as the decision-making of a minority for the whole of society:

But this is certain, seeing right reason is not existent, the reason of some man, or men, must supply the place thereof; and that man, or men, is he or they, that have the sovereign power [. . .]; and consequently the civil laws are to all subjects the measures of their actions, whereby to determine, whether they be right or wrong, profitable or unprofitable, virtuous or vicious; and by them the use and definition of all names not agreed upon, and tending to controversy, shall be established. As for example, upon the occasion of some strange and deformed birth, it shall not be decided by Aristotle, or the philosophers, whether the same be a man or no, but by the laws.

(EL 2.10.8; Hobbes 1994, 181)

Hobbes's political theory is an absolutism based on epistemological relativism. Its foundational assumption is that multitudes of people are incapable of acting according to a rational consensus. The lack of objective rational criteria for human action requires the coordination of individual moral judgements by the sovereign (L 1.6; Hobbes 1996, 39).

In his reflections on pedagogy, Hobbes is particularly suspicious of books and book knowledge. The contemporary epistemology of reading, as we have seen, confirms this suspicion. As we have seen, the meaning of words for Hobbes is always dependent on their use in a defined or definable context; theoretically, the only solution to the problem of contingency is to have the meaning of disputed terms

50 The word "magnifying" might be read as an early instance of the optical metaphor elaborated in Leviathan 2.17: "that art of words, by which some men can represent to others, that which is Good, in the likenesse of Evill; and Evill, in the likenesse of Good; and augment, or diminish the apparent greatnesse of Good and Evill; discontenting men, and troubling their Peace at their pleasure" (Hobbes 1996, 119-20). 
assigned by the sovereign. This makes Hobbes very sceptical of the success of learning from books, because books lack a clear indication of the "contexture" of their utterances (EL 1.13.8; Hobbes 1994, 76). This accounts for the difficulty of discovering the author's true "opinions and intentions". In contrast, this problem is not nearly so severe in "the presence of him that speaketh", because in situations of interaction we can infer, from "sight" and perhaps from other means of guessing the speaker's present intentions, what he means to say (76-77). But for printed texts, it is easier to persuade than to teach.

It is therefore quite understandable that control over what was being printed and published should be a major political and governmental concern. If, because of its physiological, especially visual foundations, the act of reading, like rhetoric, appeals to the passions more than to the intellect, this influential ideological weapon has to be controlled and used for the 'right' purpose - which can only be defined by the sovereign. This is even more important because, by means of print, rhetorically skilful demagogues can enormously expand the pernicious influence of their inflaming words and endanger the stability of the political order. In the absence of firm moral criteria for individual decision-making, the prince has to govern by manipulating his subjects' beliefs in order to ensure public peace:

[I]t is annexed to the Soveraignty, to be Judge of what Opinions and Doctrines are averse, and what conducing to Peace; and consequently, on what occasions, how farre, and what, men are to be trusted withall, in speaking to Multitudes of people; and who shall examine the Doctrines of all bookes before they be published. For the Actions of men proceed from their Opinions; and in the wel [sic] governing of Opinions, consisteth the well governing of mens Actions, in order to their Peace, and Concord.

(Hobbes 1996, 2.18, my italics)

We have now come close to discerning the specific function of literary communication, which Hobbes elaborates in close connection to his political, anthropological, and epistemological considerations. In Hobbes's diagram of the "SUBJECTS of KNOWLEDGE" in Leviathan 1.19, poetry is classified as a branch of natural philosophy, on a par with rhetoric, logic, and jurisprudence. Poetry is not an autonomous realm of study but one of the disciplines concerned with language. The distinction between poetry and eloquence appears to be rather fluid, as Hobbes derives the very definition of poetry from rhetorical epideixis: "Magnifying, Vilifying, \&c." $(1996,61)$. Poetry communicates opinions that influence the passions, similar to the 'colours' of rhetoric. It makes isolated fragments of reality appear greater than they really are by means of an optical trick. Poetry uses "Metaphors, and Tropes of speech" ( $L 1.4 ; 1996,31)$ that work on the fancy rather than judgement: in poetry, these 'inconstant' forms of signification have a decorative rather than persuasive function; they are "less dangerous, because they profess their inconstancy" (31).

Poetry for Hobbes is legitimate as innocent play with words, its purpose "to please and delight our selves, and others, by playing with our words, for pleasure or ornament, innocently" ( $L$ 1.4). The 'danger' arises when poetic use of speech is 
confused with the literal, when the line that separates poetry from persuasive rhetoric is crossed and "reasoning" is based on metaphors instead of definitions - which can only lead to "contention, and sedition" $(1.5 ; 36)$. Judgement is therefore needed to keep this line of demarcation between poetry and rhetoric stable. In Hobbes's thought, the boundary between fictional and factual modes of representation is not systematic and clear-cut; like the meaning of words, these modes are dependent on context and use. This is quite clearly stated in The Elements of Law (1.13.7):

Another use of speech is INSTIGATION and APPEASING, by which we increase or diminish one another's passions; it is the same thing with persuasion: the difference not being real. [. . .] And as in raising an opinion from passion, any premises are good enough to infer the desired conclusion; so, in raising passion from opinion, it is no matter whether the opinion be true or false, or the narration historical or fabulous. For not truth, but image, maketh passion; and a tragedy affecteth no less than a murder if well acted.

(Hobbes 1994, 76)

Imaginative literature, independent of genre - "whether it be Epique, or Dramatique" ( $L 1.8 ; 1996,51)$ - has an effect on its readers or audiences because it works upon the passions. It is this performative character of producing opinions from passions that counts in Hobbes's theory, rather than formal definitions of genre. The end here justifies the means: "any premises are good enough to infer the desired conclusion" (1994, 76). The psychological effect (arousal or appeasement) depends on the context in which it occurs, on the intention of those who wish to produce it, and on the degree of perfection in the performance ("if well acted"). Apparently, Hobbes is here thinking in terms of larger audiences, crowds in a Greek amphitheatre or an English playhouse. When he does consider individual readers, he emphasises the production of fictitious images in the mind: "when a man compoundeth the image of his own person, with the image of the actions of an other man; as when a man imagins himselfe a Hercules, or an Alexander, (which happeneth often to them that are much taken with reading of Romants) it is a compound imagination, and properly but a Fiction of the mind" ( $L$ 1.2; 1996, 16). Here he actually talks about reading novels, describing a Don Quijote situation of identifying with a fictional character. The meaning of the word "image" in this passage is complex; if it is related to the phrase "image maketh passion" cited above, it becomes clear that "image" cannot only be understood here as a visual representation in the mind but needs to be read as a representation that is 'coloured' by opinion: to imagine oneself a Hercules is to have an enlarged opinion of one's own abilities or one's heroic character. An image, in this sense, can never be true but must always have a certain falsifying or beautifying spin to it.

Evidently, Hobbes for the most part does not think about literature in aesthetic terms. This is not because such terminology would not have been available to him (Neoplatonism as well as French neoclassicism would have offered him ample precedents); rather, he deliberately avoids it for strategic reasons. Instead, he writes about poetry in terms of a psychology of perception - a decisive step for English neoclassicism. Not for Hobbes the Neoplatonic talk of "everlasting beauty" or "inward light" 
promoted by Sidney (Sidney 1973, 77, 91). For the materialist, after all, "[1]ight is a fancy in the minde, caused by motion in the braine, which motion againe is caused by the motion of [th]e parts of such bodies, as we call lucid" (Hobbes 1646, fol. $3^{\mathrm{r}}$ ).

Poetry, like rhetoric, has an ideological and ultimately political function for Hobbes and many of his contemporaries: its purpose is to modify the ways in which people perceive their conditions of living and those who govern them. Hobbes explicates and radicalises what is already inherent in Renaissance literary theory: the connection between poetic language and human action. For Sidney, for example, poetry is not defined by formal criteria but by its intentions and effects: what makes a poet "is not rhyming and versing" but "that feigning notable images of virtues, vices, or what else, with that delightful teaching" that leads to "virtuous action" $(1973,81,83$, my italics). Hobbes, who typically thinks in terms of populations rather than individuals, transforms Sidney's celebration of poetry as "of all sciences [. . . ] the monarch" $(1973,91)$ into a pragmatic admonition to the sovereign concerning the dangers and uses of poetic language. The study of poetry, for Hobbes, is the science of controlling these dangers and converting them into useful instruments of politics.

This conception is elaborated in Hobbes's collaboration with Davenant. Although Hobbes is busy writing Leviathan, he obliges Davenant, who like him has been an exile in Paris since 1646, with a written reply to his preface to Gondibert, in which Davenant praises Hobbes as the philosophical mastermind behind his ambitious epic poem. Both the preface and Hobbes's “Answer" are printed together in Paris in 1650, a year before the incomplete poem itself - and Hobbes's Leviathan are published..$^{51}$ Hobbes's "Answer to the Preface" contains "the clearest exposition of [Hobbes's] theory of the fancy" (Skinner 1996, 333) and of his ideas of the function of poetry. Taken together, the two texts form a sort of manifesto for a materialist understanding of literature at mid-century, one year after the execution of Charles I and the proclamation of the English Republic. Surprisingly, it is Davenant, not Hobbes, who explicitly lingers on the political and ideological uses of poetry. Hobbes begins more conventionally, by repeating the commonplace Renaissance definition of the role of poets as laid down in Sidney's Defence: "by imitating humane life, in delightfull and measur'd lines, to avert men from vice, and encline them to vertuous and honorable actions" (Hobbes 1971a, 45). The matrix of poetic genres he devises to describe "the Nature and differences of Poesy" (45) is a system of correspondences between three major "sorts of Poesy" (heroic, scommatic, pastoral), "regions of the universe"

51 Davenant 1650a (Wing D334A), Davenant 1650b (Wing D322). Wing D322 has the alternative title A Discourse upon Gondibert and contains two dedicatory poems by Waller and Cowley on Davenant's "two first Books of Gondibert, finished before his voyage to America" - a short-lived enterprise, since Davenant's ship was intercepted by the republican navy and Davenant was taken back to London. Critical attention to the Hobbes-Davenant connection has been scanty. Notable exceptions are Dowlin 1934, Reiss 1982b; Sharpe 1987, 101-8; Young 1986, Jacob and Raylor 1991; Springborg 1997. 
(heaven, air, earth) and "regions of mankind" (court, city, country) (Reik 1977, 139). These "sorts of Poesy" are further distinguished "in the manner of Representation, which sometimes is Narrative [...] and sometimes Dramatique" (Hobbes 1971a, 45-46), resulting in six different genres, of which the epic poem - the genre of Davenant's Gondibert - is the highest and noblest, associated with the heroic, with heaven and the court. This matrix typifies the normative, prescriptive style of thought that dominates early modern neoclassical poetics (Reik 1977, 151, 220; Simon 1971, 15).

As in his other writings, Hobbes derives his idea of style from the rhetorical tradition: good style is what is appropriate in a given communicative situation, determined by conventional and rational principles. The ability to know what is appropriate in different situations and to act accordingly - which I take to be Hobbes's definition of "wit" ( $L$ 1.8) - depends on "judgement" (also called "Discretion", the rational ability to distinguish differences and resemblances) rather than "fancy" (associative imagination). ${ }^{52}$ Judgement is also needed to control the fancy by means of necessary restrictions: perspicuity, property, decency. "Judgement begets the strength and structure; and Fancy begets the ornaments of a Poeme” (1971a, 49). Again, Hobbes anticipates what will become a commonplace in English neoclassical literary theory: the need to exert rational control over the "Wild and Lawless" imagination. ${ }^{53}$ Yet in the context of Hobbes's thought, this competition between fancy and judgement can be explained as a reflex of his philosophical work on the relation between images and truth, rhetoric and science, which ultimately stems from a concern about the correct and virtuous handling of (performative) language. Judging from Hobbes's use of the term "image", the “copious Imagery discreetly ordered, and perfectly registred in the memory", which

52 In the "Answer", the distinction between judgement and fancy is slightly different than in Leviathan: judgement, memory's "severer Sister," "busieth her selfe in grave and rigide examination of all the parts of Nature, and in registring by Letters, their order, causes, uses, differences and resemblances"; fancy, on the other hand, is "swift motion over" the "materials at hand and prepared for use [sc., by judgement]," the high-speed mental processing of "copious Imagery" (1971a, 49). In Leviathan, Hobbes applies these terms outside of a literary context, in a wider psychological and moral significance; there, he identifies fancy (or "imagination") as the processing of resemblances and judgement as the processing of distinctions (cf. 1.8), places them in a hierarchical order of value, and adds the third term 'wit': "Fancy, without the help of Judgement, is not commended as a Vertue: but the later which is Judgement, and Discretion, is commended for it selfe, without the help of Fancy. [. . .] So that where Wit is wanting, it is not Fancy that is wanting, but Discretion. Judgement therefore without Fancy is Wit, but Fancy without Judgement not" (1996, 1.8).

53 Cf. Dryden's epistle dedicatory to The Rival Ladies (1664): “Imagination in a Poet is a faculty so Wild and Lawless, that, like an High-ranging Spaniel it must have cloggs tied to it, least it out-run the judgement” (1962, 101); epistle dedicatory to Annus Mirabilis (1666): "the faculty of imagination in the writer [. . .], like a nimble Spaniel, beats over and ranges through the field of Memory, till it springs the Quarry it hunted after" (1956, 53). Even the spaniel seems derived from Hobbes who, in The Elements of Law, compares the "quick ranging" of the mind with the "ranging of spaniels" searching for a scent (1994, 1.4.3); cf. Watson 1962, 1: 8 n. 2. On the presence of Hobbes in Dryden's writings, see Dryden 1995a, 328-29 n. 56; Winn 1987, 133-34, 216-18. 
forms the "materials" of fancy (1971a, 49), is not exclusively visual but includes rhetorical 'colours' and figures of speech. According to Quentin Skinner (1996, 365), "Hobbes's thesis is [. . . ] that the use of ornatus represents the natural way of expressing the imagery of the mind, a commitment that makes him one of the earliest writers in English to employ the general term 'imagery' to refer to the figures and tropes of speech.” Fancy is verbal as well as visual creativity, and its products are potentially deceptive unless they are supplemented and controlled by rational principles of selection, contrasting and ordering (judgement), which are the methodic foundations of science. In this respect, because he insists on a neat separation and opposition between fancy and judgement, the Hobbes of 1640 appears more 'neoclassical' than the Hobbes of 1651, who argues (and Leviathan is a rhetorical turning point in this respect, in part prepared for by the "Answer") that a case could be made not for maintaining a clear separation between the two opposed faculties or forms of wit but for establishing an alliance between them. 'Science' can then legitimately resort to rhetorical techniques of adornment and make deliberate use of imagery ("similes, metaphors, and other tropes", $E L 1.10 .4 ; 1994,61$ ) in order to persuade others of the truth of what judgement has distinguished, thereby to produce "very marvellous effects to the benefit of mankind" (1971a, 49). "For wheresoever there is place for adorning and preferring of Errour, there is much more place for adorning and preferring of Truth, if they have it to adorn" (1996, 484; see Skinner 1996, 364-66).

In the "Answer", the argument for a necessary alliance between judgement and fancy is applied to works of literature ("Poesy," "fiction": 1971a, 46, 51). This leads to a normative understanding of literary creation and literary theory, which parallels the normative definitions and demonstrations of Hobbes's moral science. In politics as well as literary theory, Hobbes is concerned with the limits of liberty, as can be seen in his proposition that "the Resemblance of truth is the utmost limit of Poeticall Liberty" (1971a, 51). This normative understanding involves establishing criteria of probability, of decorum (i.e. the observation of discursive and generic boundaries, normative distinctions between poetry and history, for example, or between the various literary 'sorts'), and the emphasis on an intramundane, empirical, and rational foundation of subject matter ("the subject of a Poeme is the manners of men, not naturall causes”, 46) and poetics. In close alignment to his political arguments against enthusiasm, Hobbes mocks those versifiers who "would be thought to speake by a divine spirit" (48) or who profess "to speake by inspiration, like a Bagpipe” (49). Making the same connection to enthusiasm, Davenant, in his Preface, calls 'inspiration' "a dangerous word” (22).

Hobbes applies to the theory of literature a literal and pragmatic (action-oriented) version of Renaissance poetics and practices of reading. As in his political writings (Tuck 1996, 193), he transposes reading and interpretation from the level of the individual reader to the level of a larger group, a multitude or an entire population, so that imaginative literature is viewed in the light of its social functions and political utility. In Renaissance theory, the conventional view of the purpose of 'true reading' had been 
to follow the advice of Plutarch: "to search for Philosophie in the writings of Poets: or rather therein to practise Philosophie, by using to seek profit in pleasure, and to love the same" (Plutarch 1603, 19-20). Readers were encouraged to extract, or to import from outside, "the moral philosophy that good authors mixed with their fictions" (Wallace 1974-75, 278) and to deduce applicable precepts from literary examples. The individual reader enjoyed a comparatively "wide latitude of response" (Wallace 1974-75, 275), but it was an early modern commonplace to assume that one read literary or historical texts for the purposes of (mostly moral) applicability, and that literary texts contained arguments about moral or philosophical truth that could be explicated in sententiae (Jardine and Grafton 1990).

Hobbes, in the "Answer", effectively turns this idea on its head, transforming a programme of aesthetic reception into a norm of aesthetic production. His question is not how an utterance could be extracted from a text by the reader, but how the author must construct a text so that it will impart a certain message and produce the intended effect upon its readers. In other words, Hobbes suggests solving the problem of contingency in early modern textual communication by means of a theory of effect. This effect is achieved by a method similar to the optical principle of the prospective glass:

I beleeve (Sir) you have seene a curious kind of perspective, where, he that lookes through a short hollow pipe, upon a picture conteyning diverse figures, sees none of those that are there paynted, but some one person made up of their partes, conveighed to the eye by the artificiall cutting of a glasse. I find in my imagination an effect not unlike it from your Poeme. The vertues you distribute there amongst so many noble Persons, represent (in the reading) the image but of one mans vertue to my fancy, which is your owne; and that so deeply imprinted, as to stay for ever there, and governe all the rest of my thoughts, and affections [. . .].

$(1971 \mathrm{a}, 55)$

While reading, the reader's fancy is "deeply imprinted" with an "image" of "vertue", an image that the text does not contain on the surface, explicitly, but which it communicates to the mind by an optical trick: uniting fragments of an image into an unexpected new image. The image that appears is "some one person made up of their partes", which exactly corresponds to the Hobbesian principle by which political sovereignty is constructed and which the artist of the Leviathan frontispiece presents as a visual composite image: "the Multitude so united in one Person" ( $L$ 2.17; 1996, 120). This 'imprint' is "to stay for ever" in the reader's mind "and governe all the rest of [his or her] thoughts" (1971a, 55). The poem has reached its intended goal when it has fulfilled its function of moral teaching by permanently imprinting the master image of the composite sovereign.

Hobbes commends Davenant's heroic poem for achieving this ideal goal, but also because the content of its teaching corresponds to Hobbes's own political philosophy: "when I considered that also the actions of men, which singly are inconsiderable, after many conjunctures, grow at last either into one great protecting power, or into two destroying factions, I could not but approve the structure of your Poeme, which ought to be no other then such an imitation of humane life requireth" (1971a, 50). For "such an imitation of humane life", the aid of metaphysical 
concepts is no longer required, but such notions can still be reinscribed as a metaphoric illustration of a rational theory; as is the case when Hobbes gives a hermeticist description of the "wonderfull celerity" of the imagination that can "fly from one Indies to the other, and from Heaven to Earth [. . . ], into the future, and into her selfe, and all this in a point of time" (49), or when he compares the influence of the stars on human behaviour with the influence of the sovereign: "For there is in Princes, and men of conspicuous power (anciently called Heroes) a lustre and influence upon the rest of men, resembling that of the Heavens" (45). ${ }^{54}$ Hobbes reads Davenant's poem as a device in which this "influence upon the rest of men" is literally operative: its "motive" is "to adorne vertue, and procure her Lovers" (48), i.e. to persuade readers of the sovereign's "vertue" and to convince the individuals that make up the commonwealth that they have to be lovers of virtue: to form a composite image of their unity, in obedient submission to a sovereign, for the sake of peace and security. In the "Answer", Hobbes himself applies the principles of his theory to this brief text: the image that the reader is supposed to see has to be composed from disparate fragments and "diverse figures" in the text. Shortly after this, the technique of this "curious [. . .] perspective" (55) is graphically applied to the title page of Leviathan. In the literary and then visual production of this composite image, the conflict between visual and literary rhetoric is finally reconciled.

A greater contrast than between Milton on the one hand and Hobbes and Davenant on the other can hardly be imagined. And yet they sometimes employ similar metaphors and conceits that document what they have in common despite extreme differences in class, religion, and political conviction. After all, they have all imbibed a typical Renaissance education and rhetorical training. Moreover, they share a common problem, perhaps the most fundamental political problem of the seventeenth century: how to resolve or at least to reconcile the tricky relation between the 'state' and 'the people', the interests of power and the interests of liberty. Although their proposed solutions are as different as they can be, their means of finding possible answers are the same, stemming from the same traditions of literary culture and education. None of them are blessed with success: Davenant's major poem turns out to be a busted flush; Hobbes's Leviathan fails to find favour with the exiled court and is banned after the Restoration; Milton already writes Paradise Lost in the political underground, vaguely hoping for a "fit audience [. . .], though few" (Milton 1998, 7.31). And yet some of Hobbes's ideas and even some of his expressions show up again in the liberal political theory of John Locke in the 1680s, and Davenant's rationalist poetics at least enjoyed something of an afterlife during the Restoration and beyond (Gladish 1971, xxiii). In order to see how a poet

54 Both comparisons also occur in Davenant's Preface: “Witte is [. . .] dexterity of thought; rounding the world, like the Sun, with unimaginable motion; and bringing swiftly home to the memory universall survays" $(1971,18)$; on astrological influence, cf. 13, 38. 
intends to apply Hobbes's theories of optics, of politics and of the physiology of reading in a programmatic manner, we must now turn to Davenant's Preface to Gondibert.

\section{"The Conquests of Vertue": Mimesis and Strategic Visuality in Davenant's Preface to Gondibert (1650)}

In contrast to Hobbes's “Answer”, Davenant's own preface is anything but softspoken. He straighforwardly recommends his Gondibert as an ideological tool for inculcating obedience to the sovereign, offering it as a form of political advice to the monarch. Its political message is a justification of absolute sovereignty in Machiavellian terms, which is legitimised not by divine decree but by the presence of inner-worldly problems and demands (Davenant 1971, 30, 36). Consequently, like Hobbes, he excludes the supernatural from his concept of epic poetry (6). In its historical and social context, Davenant's preface can be read as a store-house of political and literary clichés, but like Hobbes's “Answer”, it has been influential for the development of English neoclassical criticism.

Written and published at mid-century, the Preface to Gondibert sums up moral, aesthetic, and political discussions of its time, not in the manner of an academic analysis but from a certain perspective and with a clear political intention: it is an actionand goal-oriented utterance directed at a royalist courtly audience. Its context is the Civil War and the abolition of the monarchy in England: at the time of writing, the execution of Charles I in 1649 is still a recent event; Charles II has made his famous escape from England and is now a twenty-year-old exile without political power. Even absolutist France is shaken by violent outbreaks of civil unrest: in 1649, the Fronde revolt temporarily forces the French royal family to withdraw to Saint Germain (Knachel 1967). The text's immediate audience is the royalist community in Paris, not least Charles II himself, but its background (like that of Leviathan) is a more fundamental political conflict between sovereign and parliament that has a continental dimension as well. The text is confidently located by Davenant at the centre of power where the French sovereign has been reinstated: "From the Louvre in Paris / January 2. 1650" (i.e. 1651). But it is not surprising then that many of the metaphors and similes used by Davenant are derived from warfare - ambush $(1971,18,24)$, scout $(18,23,26)$, forces (25), enemy $(17,23,26,33)$ conquest (39), etc. - since he had himself seen military action during the war.

The preface addresses Hobbes in the style of a letter, using him as a philosophical authority, a representative of the 'new science' and a "Guide" across the battlefield of learning (24). Like Hobbes, Davenant is concerned with the very same question that led Burton and Browne to devise complex literary strategies: how to cope with the precarious relation between authors and readers in print culture, if communicative intentions are difficult to find out (by the reader) and equally difficult to achieve (by the 
author)? Davenant's answer is radically simpler than all those we have encountered until now. For him, critics and readers are all "Enemyes" (17) of writers. The author has to conquer or overpower the reader in military fashion. He does not complain about this predicament; he merely explains it by the "imperfect Stomacks" of readers who "either devoure Bookes with over hasty Digestion, or grow to loath them from a Surfet" (25). The cause of readerly indigestion is literary overproduction, which leads to a loss of interest or understanding: "so shy men grow of Bookes" (24). This explains why “commonly Readers are justly Enemyes to Writers” (17). The author must become inventive: he must "court, draw in, and keep [the reader] with artifice” (24), he must "have [. . . ] successe over the Reader (whom the Writer should surprize, and as it were keep prisoner for a time) as he hath on his Enemy's” (17). Aesthetic strategies are deployed as stratagems. For Davenant, as for Milton and Hobbes, the arts of rhetoric are weapons to persuade and win an audience, turning enemies into allies and "incredulity" (11) into belief. In terms that echo Sidney, but also Milton (cf. Milton 1953a, 816-18), Davenant describes heroic poetry as the most pleasing and therefore "easy" means to "the Conquests of Vertue" (39). He even develops an early functionalist understanding of literary illusion, what Coleridge would much later call the "willing suspension of disbelief" $(1965,169)$ : "For wee may descend to compare the deceptions in Poesy to those of them that professe dexterity of Hand, which resembles Conjuring, and to such wee come not with the intention of Lawyers to examine the evidence of facts, but are content [. . . ] to pay for being well deceiv'd" (11).

In Davenant's programmatic statements, this act of deception has a didactic purpose: "to governe the Reader (who though he be noble, may perhaps judge of supreme power like a very Commoner, and rather approve authority, when it is in many, then in one)" (24). Here poetic communication is conceived as pragmatic, goal-oriented, and strategic; he avoids to tackle the contingencies of communication between authors and their audience, but opts for a solution by means of communicative strategies, namely the effective, manipulative use of literary techniques of suspense and illusion ("being well deceiv'd"). Its influence on Restoration literary theory is notable in Dryden, for example, who cites Davenant's Machiavellian understanding of the author as an absolute sovereign and the audience as his subjects who must be persuaded and conquered. These are precisely the terms in which Dryden, in "Of Heroique Playes" (1672), argues for the use of realistic theatrical effects:

these warlike Instruments, and, even the representations of fighting on the Stage, are no more than necessary to produce the effects of an Heroick Play; that is, to raise the imagination of the Audience, and to perswade them, for the time, that what they behold on the Theater is really perform'd. The Poet is, then, to endeavour an absolute dominion over the minds of the Spectators: for, though our fancy will contribute to its own deceipt, yet a Writer ought to help its operation.

(Dryden 1978, 13-14)

Davenant distinguishes the performative character of poetry from the imitative character of history, whose task is "to record the truth of [past] actions" (Davenant 
1971, 5). History is concerned with "Truth narrative, and past", poetry with "truth operative, and by effects continually alive" (11). Literature communicates a "truth in the passions" (5), but it does so "in reason" (11). Davenant's poetics is a rational one based on probability and verisimilitude (cf. 3, 16), on "explicable vertue" and "plaine demonstrative justice" (9). Poetry is judged from the perspective of utility ("how usefull it is", 28) rather than its aesthetic qualities. Poetry "charm's the People, with harmonious precepts" (30). It presents versified lessons in morality in a highly stylised rhetorical language, ultimately teaching "a willing and peaceful obedience" (30) to the sovereign monarch and towards "Superiors" in general (30).

But Davenant's poetics also has a social dimension, which strictly limits his target audience for poetry. From the noble title of the author's "Enemyes", the lower ranks of society are excluded. This saves Davenant the labour of performing complicated rhetorical manoeuvres around the problem of social cohesion and the possibility of teaching obedience to commoners by rational and linguistic means (a problem that also haunts Milton's Areopagitica). Davenant has no illusions about the usefulness of measured language in 'conquering' "the People", whom he also derogates as "the Rabble", "the meanest of the multitude" (15), and "this wilde Monster" (30). The positive influence of poetry does not reach that far down the social ladder. For Davenant, "the People" have a status no higher than animals: "They looke upon the outward glory or blaze of Courts, as Wilde beasts in darke nights stare on their Hunters Torches" (12). "The common Crowd (of whom we are hopelesse) we desert; being rather to be corrected by lawes (where precept is accompany'd with punishment) then to be taught by Poesy; for few have arriv'd at the skill of Orpheus [. . .] whom wee may suppose to have met with extraordinary Grecian Beasts, when so successfully he reclaim'd them with his Harpe" (13). The antagonism legible in these comparisons betrays an insecurity about the stability of the relation between the governors and the governed, understandable perhaps if we consider that a republic has just been established in England: the "Wilde beasts" might turn around to attack their hunters at any moment, and no Orpheus would be capable of appeasing them. Indeed, Davenant's argument sounds more Machiavellian than Hobbesian: "who can imagine lesse then a necessity of oppressing the people, since they are never willing either to buy their peace or to pay for Warre?" (12).

Davenant takes up Hobbes's optics of the passions when he explains that everyone imagines himself a sovereign, so that this egoism accounts for the people's tendency to disobey and resist (cf. 12). In analogy, divisions within the commonwealth are compared to internal divisions within individuals in a way that is theoretically diffuse and undeveloped (and which Hobbes prefers to ignore in his Answer). The problem arises from the difficulty of reconciling "publique Interest" with the rights of "Private men" (36). Unlike Hobbes, Davenant sees "the State" and "the People" as antagonists analogous to the opposition between reason and passion. His passing reference to "the Law of Nature" as a rational instead of a divine basis of legitimation (according to Davenant, the law of nature makes it our duty to act rationally and to "side with 
Reason" against passion) is a mere shadow compared to the complexities of current natural law theory:

the State and the People are divided, as wee may say a man is divided within him selfe, when reason and passion dispute about consequent actions; and if wee were calld to assist at such intestine warre, wee must side with Reason, according to our duty, by the Law of Nature; and Natures Law, though not written in Stone (as was the Law of Religion) hath taken deep impression in the Heart of Man, which is harder then marble of Mount-Sinai.

What remains unclear in this exposition is the precise relation between "Man" as an abstraction, in whose "Heart" is inscribed the law of nature, and "a man", who is internally divided between reason and passion. The abstraction remains curiously unrelated to the concrete individual who, if he could read the law of nature, would not have to "dispute about consequent actions" but would not hesitate to act with certainty according to rational principles. Hobbes's Leviathan offers a theoretical answer to this tricky question by thinking sovereignty and the multitude together, as a unity rather than in opposition; but Davenant's muddled pronouncements on this subject allow us to see how fervently such an answer was desired and sought after at midcentury.

Davenant is unable to bridge the gap between the 'usefulness' of heroic poetry for inculcating obedience to the sovereign in the upper echelons of society and its uselessness for the vulgar multitude; but he attempts to compensate for this by including a social component in his otherwise Aristotelian theory of mimesis. It is enough, he claims, to educate those who can be educated; the others will follow suit because they always imitate their "Superiors": "to Imitation, Nature [. . . ] perhaps doth needfully encline us, to keepe us from excesses" (8). Imitation is a human constant ("constant humor", 9) that checks social excesses "for the safety of mankinde [. . .] by dulling and stopping our progresse", setting "limits to courage and to learning, to wickedness and to erour" (9). Davenant here describes a social mechanism of self-control that is central to an early modern understanding of individuality: imitation is a technique of observing the self as if this observation came from the outside, from the "Opinion" of others (8). This technique enforces a moderation of the passions and promotes behaviour conforming to social norms. The heroic poem presents "patternes of human life, that are (perhaps) fit to be follow'd” (12). This view of a social 'governmentality' would also prove influential in Restoration aesthetics, in courtesy books, and education; in this respect, the seventeenth century is also the first inventor of 'pattern drill' (Salmon 1979, 26-27). The didactic ideal of imitation and repetition is still fully present at the end of the century. In the epistle dedicatory to his translation of the Aeneid, Dryden states that "[t]he shining Quality of an Epick Heroe, his Magnanimity, his Constancy, his Patience, his Piety, or whatever Characteristical Virtue his Poet gives him, raises first our Admiration: We are naturally prone to imitate what we admire: And frequent Acts produce a habit” $(1987,271)$. Earlier, in his dedication of The Conquest of Granada to the Duke of York, Dryden defended the loftiness of heroic drama in 
terms similar to Davenant's arguments: “The feign'd Heroe inflames the true: and the dead vertue animates the living. Since, therefore, the World is govern'd by precept and Example; and both these can onely have influence from those persons who are above us, that kind of Poesy which excites to vertue the greatest men, is of greatest use to humane kind" $(1978,3)$.

If techniques of social observation and imitation can transcend differences of social rank, no levelling of poetry is necessary to achieve its intended trickle-down effect, which will - by a top-down process of osmotic social mimesis beginning "from those persons who are above us" - will eventually reach even 'commoners': "Nor is it needfull”, writes Davenant, "that Heroique Poesy should be levell'd to the reach of Common men; for if the examples it presents prevaile upon their Chiefs, the delight of Imitation [. . . ] will rectify by the rules, which those Chiefs establish of their owne lives, the lives of all that behold them" (1971, 13). Having imbibed heroic poetry and having been 'conquered' by virtue, the "Chiefs" become copies of epic heroes, and their bravery and loyalty to the sovereign will in turn be imitated by their social inferiors.

This social mimesis as a functional principle of poetry is only one part of Davenant's literary theory, though. Another important aspect is the question of how the "Vertue" that poetry is supposed to teach is to be specified more concretely. Here again Davenant runs into a problem of contingency, because even the "Chiefs" are unable to agree among themselves which norms and patterns for action are politically desirable. In a striking image alluding to the contingency of Machiavellian fortuna, the state is compared to a ship driven by "uncertaine" winds while various pilots cannot agree on the right course to "the Land of Peace and Plenty" (34). The passage is a variation on the medieval topos of the 'ship of fools' but also a reminiscence of classical political theory, particularly Plato (Politikos 297e-298e, 302a): “me thinks Goverment [sic] resembles a Ship, where though Divines, Leaders of Armys, Statesmen, and Judges are the trusted Pilots; yet it moves by the means of Windes, as uncertaine as the breath of Opinion; and is laden with the People; a Freight much loosser, and more dangerous then any other living stowage; being as troublesome in faire weather, as Horses in a Storme” (1971, 34).

After presenting the different viewpoints and mutual observations of the four pilots, Davenant concludes that every party's perspective determines its perception of reality, leading them to "an emulous warr among themselves" which weakens their power. To save them from such multiple contingencies, he proposes the "collaterall help" of poetry. This time, his earlier qualifications about social restriction have curiously disappeared, because now he does suggest that poetry might serve as an ideological weapon to constrain "the People” (37):

wee shall not erre by supposing that this conjunction of Fourefold Power [Religion, Armes, Policy, Law] hath faild in the effects of authority, by a misapplication; for it hath rather endeavord to prevaile upon their bodys, then their mindes; forgetting that the martiall art of constraining is the best; which assaults the weaker part; and the weakest part of the People is their mindes; for want of that which is the Mindes only Strength, Education; but their Bodys 
are strong by continuall labour; for Labour is the Education of the Body. Yet when I mention the misapplication of force, I should have said, they have not only faild by that, but by a maine error; Because the subject on which they should worke is the Minde; and the Minde can never be constrain'd, though it may be gain'd by Persuasion: And since Persuasion is the principall Instrument which can bring to fashion the brittle and misshapen mettall of the Minde, none are so fitt aides to this important worke as Poets: whose art is more then any enabled with a voluntary, and cheerfull assistance of Nature; and whose operations are as resistlesse, secret, easy, and subtle, as is the influence of Planetts.

Uneducated minds are easy prey for rhetorical weapons of mass persuasion. For Davenant, heroic poetry is of "particular strength" in this respect because it "hath a force that overmatches the infancy of such mindes as are not enabled by degrees of Education" (38).$^{55}$ In terms recalling Francis Bacon's celebration of the new science as an attack on nature (imagined as a woman to be 'enjoyed'; cf. 17), Davenant presents the conquering of people's minds as a "ravishment of Reason" (38). Yet whereas Bacon's aggressive scientific exploration is meant to produce an increase of scientific knowledge, Davenant's "delightfull insinuations" (38) are to generate political obedience in a proto-behaviorist act of 'imprinting', which may also echo Descartes's argument for manipulating emotional responses to sensory stimuli in his Passions de l'Ame of 1649 (Jacob and Raylor 1991, 219).

Similarly, Davenant's definition of wit as "dexterity of thought; rounding the world, like the Sun, with unimaginable motion; and bringing swiftly home to the memory universall survays" (18) not only presents an allusion to hermeticist traditions, probably mediated through Italian Neoplatonism. ${ }^{56}$ Its construction of a (geocentric) equivalence between the 'motion picture' of imagination and the motion of the Sun also implies a panoptic, controlling, and hierarchical observer position (Foucault 1979). Flatteringly, Davenant's praise of Hobbes places the philosopher in this privileged solar position: he travels "like the Sun" to "enlighten the world" (24). As in Aristotelian optics, seeing and emitting light are the same process. Rather than a glimpse of transcendence, Davenant's poetry is to provide "universall survays" of "the world". Wit, for Davenant, is the ability to survey the volatility and complexity of the world, like a solar sovereign (the image anticipates Louis XIV's description as Roi Soleil) and to influence this reality. "[A]ll that finde its strength [. . .] worship it for the effects" (18, my italics). These effects of wit could be specified according to different offices (Condren 2002), different duties or roles, as perceived qualities of successful

55 The contradiction between this passage and the earlier exclusion of the common people from the persuasive powers of poetry is only resolved in Davenant's later Proposition for Advancement of Moralitie (Jacob and Raylor 1991), where he argues for the utility of heroic multi-media spectacles in educating the 'vulgar', effectively democratising the court masque. Perhaps what he has in mind is a distinction between two kinds of poetry for two different audiences, an elevated style for the educated and a simple style for the uneducated.

56 Francesco Patrizi's Nova de Universis Philosophia (1593) was contained in Hobbes's 'ideal library' (Pacchi 1968). 
social action: "It is in Divines Humility, Exemplarinesse, and Moderation; In Statesmen Gravity, Vigilance, Benigne Complaisancy, Secrecy, Patience, and Dispatch. In Leaders of Armys Valor, Painfulnesse, Temperance, Bounty, Dexterity in Punishing, and rewarding, and a sacred Certitude of promise. It is in Poets a full comprehension of all recited in all these; and an ability to bring those comprehensions into action" (Davenant 1971, 18-19). The function of poetry is to recall "the true measure of what is of greatest consequence to humanity, (which are things righteous, pleasant and usefull)" (19). This function is exclusively secular and rational: it is to negotiate the different perspectives of the proto-systemic 'official' divisions of the time (religious, political, military, legal) in a unified, higher-order perspective ("what is of greatest consequence to humanity"). Its goal is not to totalise any of these perspectives but to present a harmony in diversity. What these perspectives have in common is the classical notion of humanitas as a virtue that transcends the specifications of office, a residue that is nevertheless reserved "for potential respecification in terms of further official attributes" (Condren 2002, 116).

This perspectivism of a higher order can be linked to the comparison Davenant makes between poetry and painting, particularly the modern genre of landscape painting. Literary texts, like painting, use techniques of illusion to achieve their intended effects. Like the landscape painter who uses the technique of single-point perspective - and like the Sun, who inhabits God's birdseye view - poets, if they have wit, can aspire to be "considering" observers who visualise and control a prospect they can align along a grid (like the spider in its web, in Davenant's conceit [18]) and "represent" as "the Worlds true image" (4) to the view of other spectators. Understood in terms of perspective, wit is for poetry what the vanishing point is for painting: it ensures that the representation is configured in such a way that the spectator/reader is made to see "the Worlds true image" just as the painter/poet intended it to be seen. The truth of the image depends on the observer's perspective and can be ideologically determined ad libitum.

The Preface to Gondibert not only anticipates central points of neoclassical literary theory in England, especially from Dryden's famous essays, by a number of years - especially the rationalist understanding of poetry as "the best Expositor of Nature" (40). It is also a highly strategic text, not only reflecting on literature as a tactical instrument of power but also employing such tactics directly. Davenant uses what he perceives as the authority and influence of Hobbes to address the monarch himself, certainly with the intention of gaining favour. In 1650, Hobbes, the former mathematics tutor of Charles II, was on his way to becoming an important political advisor to the king in exile; a future destroyed shortly afterwards, most probably at the hands of Edward Hyde, with the publication of Leviathan. The extreme density of rhetorical flourishes in the preface to Gondibert, together with obsequious declarations of service to the exiled king, are evidence enough that Davenant used the preface - and doutbless Gondibert itself - as a means of self-promotion in the eyes of the 
monarch and his court. His aim was to assert not only the king's (and Hobbes's), but also his own position as chief of court poets and as a literary advisor to Charles II.

This reading can be corroborated by Davenant's own comments. In the preface, he not only reveals his bluntly utilitarian, no-nonsense attitude towards poetry but also towards his own motivations for writing. He frankly confesses "that the desire of Fame made me a Writer" (26). He is very conscious of the observation of others and thus of the presence or absence of royal favour. After the first books of Gondibert prove a critical failure, Davenant sees no point in continuing the poem and returns to a form that is more compatible with his talents - theatre. He becomes a successful theatrical entrepreneur. His gifts would make him not only the father of English neoclassicism but also of English opera (with The Siege of Rhodes, still during Cromwell's reign; Clare 2019) and of Restoration drama as well. Theatre and opera turn out to be Davenant's second and more successful solution to the problem of integrating verbal, visual, and auditory media for the sake of uniting literature and politics. In 1660, when Charles II returns to England, he authorises Thomas Killigrew and Sir William Davenant to run the duopoly of the King's and the Duke's Company. The royal warrant is drafted in Davenant's own hand (Public Record Office ms. SP 29/8/1).

If Hobbes's claim that Davenant contributed ideas to the writing of Leviathan is true, some possible points of inspiration can be found in the preface to Gondibert. They concern Hobbes's specialty: optical metaphors and perspectives. In Davenant's text, the leaders of armies observe politicians "with the Eye of Envy (which inlarges objects like a multiplying-glasse [. . .] and think them immense as Whales" (35). ${ }^{57}$ In Leviathan, this image is applied to "all men" and generalised to a definition of egoism: "For all men are by nature provided of notable multiplying glasses, (that is their Passions and Selfe-love,) through which, every little payment appeareth a great grievance" (Hobbes 1996, 2.18). Davenant also makes a comment on "the generality of men" using the image of an inverted telescope: "who think the best objects of theire owne country so little to the size of those abroad, as if they were shew'd them by the wrong end of a Prospective" $(1971,11)$. Other optical figures of speech in Davenant include the topical mirror of mimesis: "in a perfect glasse of Nature [the Heroick Poem] gives us a familiar and easy view of our selves" (3), and "Poets [. . .] should represent the Worlds true image often to our view" (4). Hobbes appears to agree with both: "Poets are Paynters: I would faine see another Painter draw so true perfect and natural a Love to the Life, and make use of nothing but pure lines" (1971a, 50), and yet he inserts a characteristic qualification that distances himself from Davenant's

57 The whale also appears in a previous passage in Davenant's text, where it is said that "the Mindes of Men are more monstrous [. . .] then the Bodies of Whales" (31). It should not be forgotten that Leviathan is the name of a biblical sea-monster, often identified with a whale (Job 40-41). Hobbes's theory uses this monstrosity as a motivation (fear) for resolving it, by transposing it to the higher order of the 'body politic', which appears monstrous only on the outside, not to those who inhabit it and are protected by it. 
self-congratulatory statements and conventional allusions: "For in him that professes the imitation of Nature, (as all Poets do) what greater fault can there be, then to bewray an ignorance of nature in his Poeme" (51-52, my italics). Hobbes appears less interested in Davenant's "perfect glasse" than in glasses that are 'artificially cut' (cf. 55) and that do not simply reproduce an image but generate a new and different image by technical means. Whether this disagreement, slight though it may appear, can be attributed to a more deep-seated divergence between Hobbes and Davenant is a question that can only be answered very tentatively (Berensmeyer 2012).

The two texts are meant to be read side by side. They were most probably conceived by Davenant as a strategic intervention in the literary and political culture of 1651, more particularly in the local court culture of the Paris exiles. In his “Answer”, by commending the poem, Hobbes goes to some lengths to avoid direct comments on the preface; his text is less an answer to Davenant's preface than a response to his poem. Whether this amounts to a veiled critique on Hobbes's part can only be a matter of speculation. Nevertheless, it is tempting to consider that the birth document of English neoclassicism could have been the outcome of a misunderstanding, with Hobbes evading any too firm commitment to Davenant's project and his (and many of his fellow royalist exiles') more absolutist ideas. In this - admittedly rather murky - light, one might detect a few ruptures in what would otherwise appear to be a strategic alignment between literature, politics, and representation at midcentury. After the Restoration, this project is continued, with slightly different emphases, by Margaret Cavendish, whose efforts to unite 'science' and 'fiction' are the topic of the next section in this chapter.

\section{Visuality and Imagination between Science and Fiction: Margaret Cavendish's Observations upon Experimental Philosophy and The Blazing World (1666)}

In Burton's Anatomy, fictionalised peritexts form part of a strategy of mobilising readers, teasing them to acknowledge the limits of their understanding. In Browne, these elements seamlessly enter the main text in order to make readers realise the plurality and contingency of perceived reality. As we found above, in the discourse of neoclassicism, the concept of fiction assumes at once a more precise and a more limited definition, as fictions are harnessed to achieve specific rhetorical effects. This is the case in Davenant and Hobbes, also to some extent in Milton. In marked distinction to humanist practices, these effects are more often allegorical and/or ironic than metaphorical. Fiction is employed as a marker of intellectual distance rather than as a medium of emotional closeness - intended to keep readers out rather than to invite them in. It is not so much geared towards fostering than controlling the reader's imagination and his/her physiognomic, identificatory or 
impassioned responses to a text. Writers resort to fiction not in order to enhance but to reduce or at least to control experiential complexity. This is one reason why the romance, for example (such as Sales's Theophania or Herbert's The Princess Cloria), uses the schematic forms of pastoral literature as a means to ignore the harsh realities of social and political 'modernisation' in the Interregnum and the Restoration; why imitations and continuations of Spenser's Faerie Queene are written; or why Davenant's ambition, during his exile in France, should be to produce a heroic epic set in medieval Lombardy.

Fictionalising as distancing is accompanied by a tendency towards an increasingly normative distinction of genres. This is promoted not only by near-formulaic theatrical productions that cling to the rules of their respective genres, but also by the increasing frequency of theoretical writings like Dryden's essays and later critical articulations by the likes of John Dennis or Charles Gildon - texts that transform reflections on literary genres into a genre of its own. In Restoration literary culture, this separation has consequences for the relation between oral/aural, visual, and verbal forms of cognition and rhetoric, which keep drifting further apart and become increasingly compartmentalised according to different functions. The tensions between visuality, oral rhetoric, and textuality that we could find in Milton, Hobbes, and Davenant become more pronounced, culminating in the normative distinction between (cognitive and abstract) reason and (visual, poetic, and concrete) fancy that will dominate the eighteenth century until it is softened again by Burke and Coleridge, among others.

This trend towards an increasingly strict separation between philosophicalscientific discourse and literary fiction is also borne out by one of the many publications by the long-neglected Margaret Cavendish, Duchess of Newcastle: Observations upon Experimental Philosophy. To which is added, The Description of a New Blazing World (London, 1666; 2nd ed. 1668). This volume is literally split down the middle between a 'scientific' and a 'literary' part, symptomatic even in its faithful reproduction of the cultural priority of natural philosophy over literary fiction. The books are bound together, though they were printed separately, with different signatures and page numbers. ${ }^{58}$ The fiction is a supplement, merely "added" to its more serious counterpart. This split has been carried even further in modern editions that treat the Observations and The Blazing World as completely separate works: one, a long neglected "serious treatise" (Lilley 1994, xxiv) of "natural philosophy in the age of scientific revolution" (O’Neill 2001, xxxv), the other its improbable and somewhat

58 In the following, I quote from the 1666 edition (as available on EEBO) but, for ease of reference, I distinguish between the Observations (Cavendish 1666a) and The Blazing World parts 1 and 2 (1666b and c) in order to keep track of the various page numbers. I am, however, always referring to the same document (Wing N857) as available on EEBO in a facsimile of a copy in the University of Illinois. 
frivolous "fictional companion piece" (Lilley 1994, xii). Some of these editions do not even mention the fact that the two were originally published in the same volume. A recent collection of critical essays on Cavendish also distinguishes - rather anachronistically - between her "non-fictional" and her "imaginative writings" (Cottegnies and Weitz 2003, 5).

What is irrecoverably lost in such a separation is the relation of contiguity between science and fiction that is staged by the very form of Cavendish's book: it combines two forms of writing even as it distinguishes between them. Yet the resulting tension can hardly be called ironic, dialectic or dialogic in a Bakhtinian sense. The fictional addendum does not establish a superior, critical, ironic or distancing perspective on its scientific companion, but is on the contrary most affirmative in that it serves to enhance, embellish, and support a number of philosophical points that have been made in the Observations. Thus The Blazing World, from within a deliberately fictionalised setting, fulfils a rhetorical purpose in the Hobbesian sense: as the intensifier of a theoretical argument. More explicitly than in other cases, the literary aspect of the work is separated from the rest; yet it is not declared autonomous but subordinated to the main body of the book, which is of considerably greater length (their proportion is roughly three to one). The space between science and fiction is not bridged but remains an open and visible gap.

How does Cavendish address the relationship between science and fiction in her writings, and how does she justify her management of their difference to her prospective readers? To answer this question, we first need to consider her particular status and communicative situation in the literary landscape of seventeenthcentury England. Cavendish writes natural philosophy from the position of an outsider: a woman with no formal education in philosophy and no official context, apart from her private circle, in which to profess and publish her ideas. Her books can be described as vanity publications: beautiful editions that she relentlessly sends to universities and with which she hopes to reach a largely unresponsive audience of male philosophers who either find her obnoxious or even pronounce her mad. Cavendish is motivated by an irrepressible urge to write and an unconcealed desire for fame (not unlike Davenant in this respect); her books are crowded with peritextual matter that appeals to the reader's recognition of Cavendish as an “Authoresse” and original genius (Douglas 2000; Rees 2003).

In her extravagant staging and celebration of authorship and originality, Cavendish even surpasses Robert Burton, who had remained much more sceptical about the possibility of authors communicating with readers in such a way as to be fully and correctly understood. One of three frontispieces commissioned by Cavendish from Abraham van Diepenbeeck in the 1650s depicts her in an empty study, above an inscription that includes the lines "Her Library on which She look's / It is her Head her Thoughts her Books" (Cavendish 1671). The empty space around her may have been intended to signify her independence from other sources, but it also illustrates her 
isolation. ${ }^{59}$ She tries to compensate for the lack of serious responses to her work by creating a dialogue with her own ideas: by publishing her own "Commentaries" (Cavendish 1666a, sig. e2 ${ }^{r}$ ) on her system of organicist materialism, ${ }^{60}$ by employing the device of fictional letters in which she compares the systems of other thinkers to her own (Philosophical Letters, 1664), and by inserting an abundance of prefaces and peritextual matter - her fifth book, Nature's Pictures drawn by Fancy's Pencil to the Life (1656), begins with no less than six prefaces to the reader.

Some would describe this phenomenon in pathological terms, and Cavendish would even have agreed with them to some extent. ${ }^{61}$ Yet one of her main objectives in celebrating her authorship and originality is to fill the empty space of public response with fictionalised elements of discourse and with a blatant and over-the-top apotheosis of her author position. Fictionalisation does not serve a purpose of concealment or mere ornament, nor is it used in a sceptical manner to question the relations between author, text, and reader (as it certainly is in Burton and Browne). It is rather used to suggest a firmly established hierarchy between these, even in soliciting the acceptance and collaboration of the "Curteous Reader" (1666a, sig. $\mathrm{d} 2{ }^{\mathrm{r}}$ ). The Philosophical Letters unfold a monologue in the form of an epistolary dialogue; in the Observations, there is a prefatory "Argumental Discourse" $\left(\mathrm{h} 1^{\mathrm{r}}\right)$ that stages "a Dispute [. . . ] between the rational Parts of [Cavendish's] Mind concerning some chief Points and Principles in Natural Philosophy” ( $\left(\mathrm{h} 1^{\mathrm{r}}\right)$, even "a war” $\left(\mathrm{h} 1^{\mathrm{r}}\right)$ between Cavendish's earlier and her more recent thoughts. In compliance with the neoclassical rhetoric of contingency, this dispute is referred "to the Arbitration of the impartial Reader, desiring the assistance of his judgement to reconcile their Controversies, and, if possible, to reduce them to a setled peace and agreement" $\left(\mathrm{h} 1^{\mathrm{r}-\mathrm{v}}\right)$.

In the Observations, the reader is directly engaged in a hierarchical dialogue in the preface "To the Reader" (Cavendish 1666a, sig. $\mathrm{d} 2^{\mathrm{r}}$ ), which Cavendish uses to explain, clarify, and comment on some twenty particular points, preempting criticism in syntactically repetitive phrases that follow the schema: 'When I say X I do not mean Y but my meaning is Z.' After these clarifications, the reader is asked to

59 On the critical reception, see O'Neill 2001, xvii-xxi. The unwillingness of her contemporaries to respond to Cavendish is best illustrated by a letter of Henry More to Anne Conway on the occasion of Cavendish's Philosophical Letters, in which More states that Cavendish "may be secure from anyone giving her the trouble of a reply" (Conway 1992, 237).

60 For a concise outline of Cavendish's system of natural philosophy see O'Neill 2001, xxi-xxv.

61 Cf. her remarks at the beginning of "The Preface to the Ensuing Treatise" in the Observations: "Tis probable, some will say, that my much writing is a disease; but what disease they will judg it to be, I cannot tell; I do verily believe they will take it to be a disease of the Brain, but surely they cannot call it an Apoplexical or Lethargical disease: Perhaps they will say, it is an extravagant, or at least a Fantastical disease; but I hope they will rather call it a disease of wit" (1666a, sig. $\left.\mathrm{c1}^{\mathrm{r}}\right)$. Cavendish gives no cause for "the disease of writing" ( $\left.\mathrm{c1}^{\mathrm{v}}\right)$, such as Burtonian melancholy, but calls writing "the onely Pastime which imploys my idle hours" $\left(\mathrm{c1}^{\mathrm{v}}\right)$. In the preface to The Blazing World, she refers to her "melancholly Life" (1666b, sig. $b^{\star} 2^{r}$ ). 
suspend judgement until (s)he has "read all” (sig. g2.2 $2^{\mathrm{r}}$ ). The reading process is thus anticipated and built into the text: a complete reading is allocated a place in the work's perfection, but it is not conceived as a creative or independent enterprise because the work is thought to contain all the answers in itself:

These are (Courteous Reader) the scruples which I thought might puzle your understanding in this present Work, which I have cleared in the best manner I could; and if you should meet with any other of the like nature, my request is, You would be pleased to consider well the Grounds of my Philosophy; and as I desired of you before, read all before you pass your Judgement and Censures; for then, I hope, you'l find but few obstructions, since one place will give you an explanation of the other. In doing thus, you'l neither wrong your self, nor injure the Authoress, who should be much satisfied, if she could benefit your knowledg in the least; if not, she has done her endeavour, and takes as much pleasure and delight in writing and divulging the Conceptions of her mind, as perhaps some malicious persons will do in censuring them to the worst.

(sig. g2.2 ${ }^{\mathrm{r}}$, italics reversed)

While her presentation of the hierarchical relationship between author and reader is based on an implicit fictionalisation of either position, her explicit concept of fiction is much more conventional and rhetorical. According to Cavendish, fiction - like the rhetorical 'images' in Hobbes - serves to make 'the conceptions of mind' more palatable and to ease the reader into accepting them as true or correct. Fiction is used to provide "pleasure and delight" $\left(\mathrm{g} 2.2^{\mathrm{r}}\right)$. But although Cavendish herself uses fictionalising strategies in establishing (or, at times, simulating) communication with her unwilling - mostly male - readers, her concept of fiction is explicitly subordinated to that of philosophy. She distinguishes very clearly between "serious Philosophy" and "Poetical fancy" (sig. Oo1 ${ }^{\mathrm{r}}$, p. 141). To fiction, the medium of fancy, is relegated a specific communicative genre and function. In her first publication, Poems, and Fancies (1653), which includes a number of poems on atoms, Cavendish excuses herself for choosing to write natural philosophy in verse: "the Reason why I write it in Verse, is, because I thought Errours might better passe there, then in Prose; since Poets write most Fiction, and Fiction is not given for Truth, but Pastime" ("To Natural Philosophers", Cavendish 1653, sig. A6 ${ }^{\mathrm{r}}$ ). As she puts it in the preface to The Blazing World: "The end of Reason, is Truth; the end of Fancy, is Fiction" (1666b, sig. b*1"). ${ }^{62}$ Here, then, as in Hobbes and Davenant, fiction is rhetorical adornment: a secret purveyor of truth or a beautiful lure for the unwary reader who is open to suggestion and willing to suspend judgement when reading certain generically marked texts in certain situations. Fiction here is in the service of aesthetic rationalism as a ruse of reason.

62 On the relation between philosophical and poetic discourse in The Blazing World, cf. Nate 2001, 210-14, who traces its Baconian and skeptical ramifications and asserts that the split between different discourses does not entail their mutual incommunicability; on p. 228, Nate also provides a useful diagram of the fictional 'worlds' of The Blazing World. Cf. Lobsien 1999, 263-87 for a reading that situates Cavendish in the contexts of early modern empiricism, skepticism, Neoplatonism, and cabbalism. 
Cavendish's subsequent works banish such explicit intrusions of fiction into the discourse of science; the desire to be taken seriously is too great to permit such trifling exercises of 'fancy'. Her later books no longer reveal the strategic game of text and genre as radically as the passage just quoted. The relationship between fiction and philosophy in her later texts is as hierarchical as her model of communication, which reflects the strictly hierarchical order of society that she supports and that she reproduces in The Blazing World in the mode of fiction.

This hierarchy is also the reason of the split between science and fiction that goes right through the volume that contains both the Observations and The Blazing World. Her justification for adding a fictional text to a scientific work of natural philosophy is a very concise argument for the distinctions between 'truth' and 'fiction', 'reason' and 'fancy', while at the same time explaining the unity of what is being distinguished:

If you wonder, that I join a work of Fancy to my serious Philosophical Contemplations; think not that it is out of a disparagement to Philosophy; or out of an opinion, as if this noble study were but a Fiction of the Mind; for though Philosophers may err in searching and enquiring after the Causes of Natural Effects, and many times embrace falshoods for Truths; yet this does not prove, that the Ground of Philosophy is meerly Fiction, but the error proceeds from the different motions of Reason [. . . ]; and since there is but one Truth in Nature, all those that hit not this Truth, do err, some more, some less; for though some may come nearer the mark then others, which makes their Opinions seem more probable and rational then others; yet as long as they swerve from this onely Truth, they are in the wrong: Nevertheless, all do ground their Opinions upon Reason; that is, upon rational probabilities, at least, they think they do[.]

$\left(1666 \mathrm{~b}\right.$, sig. $\left.\mathrm{b}^{\star} 1^{\mathrm{r}-\mathrm{v}}\right)$

Reason and truth are firmly aligned in an epistemology that is proto-Lockean in its emphasis on "rational probabilities" and neoclassical in its acknowledgment of epistemic contingency ("some may come nearer the mark then others"). This is one side of Cavendish's distinction; the other side is described in the following sentences:

But Fictions are an issue of mans Fancy, framed in his own Mind, according as he pleases, without regard, whether the thing, he fancies, be really existent without his mind or not; so that Reason searches the depth of Nature, and enquires after the true Causes of Natural Effects; but Fancy creates of its own accord whatsoever it pleases, and delights in its own work. The end of Reason, is Truth; the end of Fancy, is Fiction[.] $\quad\left(b^{\star} 1^{\mathrm{v}}\right.$, emphasis original)

Fancy, whose product is fiction, thus appears disconnected from any concern with what Cavendish calls "Truth", which she defines as correspondence to an existing reality exterior to the mind, in "Nature". But it is not wholly separate or disconnected from reason, as she explains in the following:

But mistake me not, when I distinguish Fancy from Reason; I mean not as if Fancy were not made by the Rational parts of Matter; but by Reason I understand a rational search and enquiry into the causes of natural effects; and by Fancy a voluntary creation or production of the Mind, both being effects, or rather actions of the rational parts of Matter; of which, as that is a more profitable and useful study then this, so it is also more laborious and difficult, and 
requires sometimes the help of Fancy, to recreate the Mind, and withdraw it from its more serious Contemplations.

$\left(\mathrm{b}^{\star} 1^{\mathrm{v}}\right.$, emphasis original)

In accordance with her continuum theory of matter, all "parts of Matter" $\left(\mathrm{b}^{\star} 1^{\mathrm{V}}\right)$ are unified by "a single, rational force" (O’Neill 2001, xxviii), and therefore fancy and reason, though distinct, are yet united in that both are "actions of the rational parts of Matter" $\left(b^{\star} 1^{\mathrm{v}}\right)$. They are, as it were, different genres and of different value - reason is "more profitable and useful", "more serious", while fancy serves "to recreate the Mind", "to divert" the author "and to delight the Reader with variety, which is always pleasing” $\left(b^{\star} 1^{v}\right)$ - stock elements of neoclassical literary criticism.

Despite their opposition, reason and fancy are "joined" in Cavendish's book, she explains, "as two Worlds at the ends of their Poles" (1666b, sig. $\left.b^{\star} 1^{v}\right)$ - a phrase that echoes a description of the world in the fictional text itself, in which the other world into which the heroine is transported is described as "joined close to" the North pole $(1666 \mathrm{~b}, 3)$. The image of two worlds mirrors the bipolar arrangement of the book that contains the Observations (reason, truth) and The Blazing World (fancy, fiction) in a single volume. Read alongside each other, the two texts reveal a number of obvious connections or points of contact, which are also legible as connections between scientific empiricism and literary neoclassicism. Fancy provides an alternative, less rigorous purchase on the observations of reason. As "a voluntary creation or production of the Mind" $\left(b^{\star} 1^{\mathrm{V}}\right)$, it triggers an unconstrained process of imaginary worldmaking that can at the same time function as unlimited (and hence unexpectedly democratic) wish-fulfilment, as documented by Cavendish's concluding remarks in the preface:

though I cannot be Henry the Fifth, or Charles the Second, yet I endeavour to be Margaret the First; and although I have neither power, time nor occasion to conquer the world as Alexander and Cæsar did; yet rather then not to be Mistress of one, since Fortune and the Fates would give me none, I have made a world of my own: for which no body, I hope, will blame me, since it is in every ones power to do the like.

$\left(\mathrm{b}^{\star} 2^{\mathrm{r}}\right.$, emphasis original)

Cavendish here transforms Hobbes's cautionary statement about the potential dangers of excessive imaginative reading into a celebratory argument for the powers of fiction. Hobbes had commented on the 'compounding' of images in the fancy in a passage worth quoting again: "So when a man compoundeth the image of his own person, with the image of the actions of an other man; as when a man imagins himselfe a Hercules, or an Alexander, (which happeneth often to them that are much taken with reading of Romants) it is a compound imagination, and properly but a Fiction of the mind" (L 1.2; Hobbes 1996, 16).

As we have seen, the word 'image' for Hobbes not only denotes a visual impression in the mind, but also involves an emotional or opinion-based colouring that can be used for rhetorical effects of intensification. This explains the usefulness of 'images' for poetry. If, for Hobbes, Cavendish's compensatory self-magnification must have had a Quixotic aspect of the delusional about it, for Cavendish herself this 
pathological dimension of the fancy is cushioned by the liberty of imaginative fiction as a distinctive genre, a type of communication where the ordinary rules of truth and decorum do not apply. Fiction is here already a mode of mere play, distinct and disconnected from reality or seriousness. This is why Cavendish can dare to hope that "no body [. . . ] will blame" her for it $\left(b^{\star} 2^{r}\right)$. This distinction is enabled by a clear, rationalist separation between different domains of discourse, a distinction which in turn enables the observation of connections between these separate domains.

One such connection between the Observations and The Blazing World is the epistemological problem of modern optics, telescopy, and microscopy. The book is at least in part a response to Robert Hooke's Micrographia of 1665 and an attempt at a "devaluation of optical science" (Linden 2001, 614; cf. Battigelli 1996). In the Observations, Cavendish is extremely critical of optical instruments. In the "Preface to the Ensuing Treatise", she maintains that "the Art of Augury was far more beneficial then the lately invented Art of Micrography; for I cannot perceive any great advantage this Art doth bring us" (1666a, sig. c2v). She regards "most of these Arts" as "Fallacies, rather then discoveries of Truth" and as a deception of the human senses that "cannot be relied upon" (sig. d1 ${ }^{\mathrm{r}}$ ). Major sections of the text are concerned with an elaboration of this argument in direct response to Hooke and to Henry Power's Experimental Philosophy of 1664: cf. chapter titles such as "Of Micrography, and of Magnifying and Multiplying Glasses”, "Of Pores”, "Of the Eyes of Flies”, "Of the Seeds of Vegetables”, "Of Telescopes” etc. In a satirical vein, this topic of telescopy and microscopy returns in The Blazing World, where the Empress institutes academic “societies of the Vertuoso's” (1666b, 19) with whose members she engages in intellectual disputes, asking them questions about the substance of the air, about "how Snow was made" (23) or about "the nature of Thunder and Lightning” (25). In a fit of passionate anger at the epistemic insufficiency of telescopes, the Empress commands her "Bird-men" to destroy them because they "are false Informers, and instead of discovering the Truth, delude your senses" (27). After some dispute, she agrees to allow them to keep their glasses, but only "upon condition, that their disputes and quarrels should remain within their Schools, and cause no factions or disturbances in State, or Government” (28).

In the framework of her fictional world, Cavendish makes a statement about art and science that is profoundly Hobbesian. Like the potentially delusive impact of fiction, the potentially seditious effects of scientific disputes need to be kept firmly in check - by means of a careful differentiation of discursive levels. Her hierarchical concept of society allows for a contingent plurality of competing and differing voices, but only if they "confine [their] disputations to [their] Schools, lest besides the Commonwealth of Learning, they disturb also Divinity and Policy, Religion and Laws, and by that means draw an utter ruin and destruction both upon Church and State" (1666b, 59-60). The need to control transgression, including excessive curiosity, is almost paradoxically foregrounded in this text: "Natural desire of knowledg [...] is not blameable, so you do not go beyond what your natural reason can 
comprehend" (86). While the Empress acknowledges that "no particular knowledg can be perfect" (59), she does not transfer this insight to her understanding of politics and religion. In these respects, The Blazing World contains an unmistakable plea for religious uniformity and unquestioning obedience to the sovereign. In the utopian counter-world of the Blazing-world, monarchy is presented as "a divine form of government", for the simple reason that "as there is but one God, whom we all unanimously worship and adore with one Faith, so we are resolved to have but one Emperor, to whom we all submit with one obedience" (16). Monotheism, unity of religious worship, and political obedience are combined into one overarching unity. When the Empress converts the religiously underdeveloped Blazing-world to her own religion, she wisely pursues a course of non-violent persuasion, echoing Davenant's arguments about public education:

And thus the Emperess, by Art, and her own ingenuity, did not onely convert the Blazingworld to her own Religion, but kept them in a constant belief, without inforcement or blood-shed; for she knew well, that belief was a thing not to be forced or pressed upon the people, but to be instilled into their minds by gentle perswasions; and after this manner she encouraged them also in all other duties and employments, for Fear, though it makes people obey, yet does it not last so long, nor is it so sure a means to keep them to their duties, as Love.

These lines about the "gentle perswasions" of "Love" are in stark contrast to a later statement, made in the text by the Duchess of Newcastle herself, whose soul enters the Blazing-world to act as a scribe to the Empress. Here the Duchess declares that "the chief and onely ground in Government, was but Reward and Punishment" (92). Whereas the Empress appears to follow the teachings of Hobbes and Davenant, the Duchess has apparently internalised the Machiavellian precepts of her husband, William Cavendish, whose Advice to Charles II on the eve of the Restoration is of a similar bluntness (Cavendish 1984; Condren 1993). When the Duchess tries to invent a world according to Hobbesian principles of pressure and counterpressure, she ends up with a headache (Cavendish 1666b, 100). The Duchess advises the Empress to maintain the principles of uniformity she has established:

to have but one Soveraign, one Religion, one Law, and one Language, so that all the World might be as one united Family, without divisions; nay, like God, and his Blessed Saints and Angels: Otherwise, said she, it may in time prove as unhappy, nay, as miserable a World as that is from which I came, wherein are more Soveraigns then Worlds, and more pretended Governours then Governments, more Religions then Gods, and more Opinions in those Religions then Truths; more Laws then Rights, and more Bribes then Justices, more Policies then Necessities, and more Fears then Dangers, more Covetousness then Riches, more Ambitions then Merits, more Services then Rewards, more Languages then Wit, more Controversie then Knowledg, more Reports then noble Actions, and more Gifts by partiality, then according to merit[.]

(121-22)

Cavendish here uses the topos of the inverted world, familiar from utopian narratives since More's Utopia, only she inverts the narrative situation to let a character from the familiar world give an account of it in the imaginary counter-world. The polemical 
intent of The Blazing World - as a celebration of absolutist values in Restoration England - is evident. It is only apparently paradoxical that her panegyric to monarchy as the most natural and rational form of government should be couched in an epistemology of contingency that evokes imperfection, the plurality of worlds, and an ethical imperative of moderation. ${ }^{63}$

Earlier, the Empress had conceded academic freedom to her scientists on condition that their pursuits be "beneficial to the publick" (48); now the Duchess enjoins her "to dissolve all their societies; for 'tis better to be without their intelligences, then to have an unquiet and disorderly Government" (122). It is this inner strength of her reformed state, we are invited to assume in the course of the narrative, that allows the Empress to win the sea-battle in the second part, reigning as she now does "most happily and blessedly" $(1666 c, 1)$. From the point of view of the Hobbesian sovereign, the phrase from La Fontaine's fable of the wolf and the lamb is affirmed: "la raison du plus fort est toujours la meilleure" (La Fontaine 1991, 44).

It is this political dimension of literary culture that Cavendish's text envisages in terms of absolutism even as it operates according to the rules of an imaginary liberalism. Literary communication, for Cavendish, is a means to realise phantasies of absolute sovereignty in a literary setting - transforming the harmful delusion of every subject (according to Davenant and Hobbes) into a politically harmless fictional game. Everyone can be an absolute monarch in a fictional world of their own making, as the spirits of the Blazing-world explain to the Duchess and the Empress:

But we wonder, proceeded the Spirits, that you desire to be Emperess of a Terrestrial World, when as you can create your self a Celestial World if you please. What, said the Emperess, can any Mortal be a Creator? Yes, answered the Spirits; for every humane Creature can create an Immaterial World fully inhabited by immaterial Creatures, and populous of immaterial subjects, such as we are, and all this within the compass of the head or scull; nay, not onely so, but he may create a World of what fashion and Government he will, and give the Creatures thereof such motions, figures, forms, colours, perceptions, \&c. as he pleases, and make Whirlpools, Lights, Pressures and Reactions, \&c. as he thinks best[.]

(1666b, 96-97)

For Cavendish's own authorship, as she presents it in "The Epilogue to the Reader", this means that she esteems literary sovereignty more highly than political power: "By this Poetical Description, you may perceive, that my ambition is not onely to be Emperess, but Authoress of a whole World[.] [...] And in the formation of those Worlds, I take more delight and glory, then ever Alexander or Cæsar did in conquering this terrestrial world" (1666c, sig. Ii1 ${ }^{\mathrm{r}}$ ). She counters the heroic imagination as described by Hobbes ("as when a man imagins himselfe a Hercules, or an Alexander" ( $L$ 1.2; 1996, 16) with her own self-glorification in the mode of fiction:

63 "I perceive that the greatest happiness in all Worlds consist in Moderation" (Cavendish 1666b, 105). On the plurality of worlds, see Cavendish 1666b, 105. Cavendish here anticipates Fontenelle's Entretiens sur la pluralité des mondes of 1686 (Lobsien 2003). 
I [. . .] instead of the figures of Alexander, Cæsar, Hector, Achilles, Nestor, Ulysses, Helen, \&c. chose rather the figure of Honest Margaret Newcastle, which now I would not change for all this terrestrivl [sic] World; and if any should like the World I have made, and be willing to be my Subjects, they may imagine themselves such, and they are such; I mean, in their Minds, Fancies or Imaginations; but if they cannot endure to be subjects, they may create Worlds of their own, and Govern themselves as they please[.]

(1666c, sig. $\operatorname{Ii1}^{\mathrm{v}}$ )

Only in fiction, in a world of the imagination, can subjects become sovereigns or subject themselves to others at their own free will. By means of her literary creativity, Cavendish not only gains freedom from her temporal, worldly troubles for the time being; she is also able, at least for a while, to harmonise private fancy with public reason and to defuse the conflicts between visuality and rhetoric, philosophy and imaginative literature, knowledge and power that otherwise continue to torment English literary culture in the seventeenth century.

\section{Literary Worldmaking}

In the early modern period, the relations between authors and their addressees become asymmetrical and contingent. What follows from this are numerous attempts to restructure these relations: in a hierarchical, absolutist manner (as in Davenant and Cavendish) or in a republican, prophetic fashion (as in Milton), but in each case involving a pedagogic and at times polemic component. Political models of textuality arise from the necessity to bridge the gap between author and audience. Milton's Areopagitica (see below) unfolds one such model, Davenant's Preface to Gondibert another; Hobbes, Cavendish, and Dryden also each reflect, more or less explicitly and in their different ways, political preconditions and strategies of literary communication. Neoclassicism develops its global strategy of rational method and hierarchical communication partly in response to political experiences of contingency.

Contingency and uncertainty are addressed in the writings of Thomas Browne, but they are ultimately presented as unproblematic against a theological background that is non-negotiable: secular contingency is itself viewed as contingent in relation to the eternal stability provided by the grace of God. At the end of days, the Last Judgement will resolve any secular differences once and for all. What follows from this belief, however, is that it would be an act of hubris for mere mortals to attempt to solve the knotty problems of religion and philosophy in this world. Political and social differences may be experienced as problematic but it is safer, in this view, to ignore their pressures on reality. What Browne lacks is a language beyond the humanist and classical heritage to connect his intellectual concerns with the political questions of his time. To do so, he would have to develop a concept of social contingency in close alignment to his philosophical concept of contingency; but this seems out of his reach. For Browne, a particular order of society, a particular distribution of rights and property, even a particular religious orientation of 
some flexibility and tolerance are indisputable social norms that should be immediately obvious to any well-intentioned citizen or 'person of quality'. This may help explain the very real shock, the horror that Browne feels and that he registers in 1643 when faced with the unthinkable - the destruction of the political order as he knows it. The fate of his text and the imminent toppling of the monarchy are parallelled in the preface to Religio Medici and the letter to Digby. The "liberty of these times" (Browne 1964a, 76) is a perversion of the natural order manifested in the breakdown of censorship and the changing world of literature. Here textuality and politics converge for Browne. In the textual noise of the Civil War, his draft of a flexible, non-persuasive rhetoric is a damp squib. It is time for more aggressive rhetoricians on both sides of the political and religious spectrum.

Browne's humanist analogy between exterior and interior, secular and spiritual nature (in The Garden of Cyrus) is secularised in Izaak Walton's Compleat Angler. Against the backdrop of the political events of the English Civil War, Walton creates a pastoral counter-world that is obviously fictional. The garden is now an artificial paradise, placed in opposition to civilisation, and its loss is merely registered with some wistfulness but, in contrast to Milton, without any eschatological or even political vision. In Margaret Cavendish, we have found a similar fictional counter-world that is playful and, even though it contemplates a distinctly feminine counter-world, remains a fantasy. The Blazing World uncovers and constructs a region of individual political fantasy by rehearsing and radicalising a neoclassical materialist perspective on the psycho-social function of poetry. The imaginary sovereign who is synthesised in Hobbes's Leviathan and from the fragments of Davenant's Gondibert finds his female counterpart in Cavendish's Empress governing "most happily and blessedly" (Cavendish 1666c, 1) - in part because she is able to preserve her dominion from the irruption of epistemological contingencies in the shape of deceitful telescopes. Thus the topic of visuality leads us, almost inevitably, from epistemological to political questions. In neoclassical discourse (poetic, scientific, political), definitions of what is to count as rational and natural are inflected by political and historical contingencies. It is these contingencies that the following chapter will set out to analyze in greater depth, focussing on ideas of the 'state of nature' in the political imaginary and in literary culture between Civil War and Restoration. As we shall see, debates about nature and natural law are an important part of literary theory, rhetoric, and literary practice in seventeenth-century England. In these debates, the conflicts between visual, verbal, and aural forms of communication are not so much resolved as transposed to a different stage, a stage prepared by the increased awareness that the division between natural and political norms, exacerbated by the Civil War and its reflections on social theory, can no longer be healed.

To "chuse to create another World" (Cavendish 1666c, sig. Ii1 ${ }^{\mathrm{v}}$ ), then, is a tempting possibility, especially for writers, but not as easy as the epilogue to The Blazing World makes it sound. Even purely imaginary fictional worlds tend to bear the traces of the reality in and for which they were created. During the Interregnum, when 
Royalists turned to the genre of heroic romance, they created fictional counter-worlds opposed to the political reality of their time. For Davenant's Gondibert as well as for Walton, these fictional worlds still carry political meaning, but only as distinct from 'real' politics, which takes place on entirely different battlefields. Even Davenant's preface, with its brutal assertion of the political function of epic poetry, cannot change this; the humanitas it professes to sponsor as 'virtue' remains a formulaic void. The chivalry of Gondibert's Lombard knights turns into an allegory that runs at a standstill, out of touch with the political reality around 1650 but still under the "form and pressure" (Hamlet 3.2) of its time.

Although this political reality is about to change yet again with the Restoration, the rupture between nature and civitas that is reflected in these texts can no longer be completely healed despite all efforts in this direction. This is certainly due in part to far-reaching discursive and economic changes (Schweikart 1986; Sennett 1994, 255-81). The court of Charles II, attached to an idealised and nostalgic view of the Elizabethan age, distances and isolates itself further from its more flexible, heterogeneous, and dynamic urban and parliamentary environment. This contrary development almost inevitably leads to an overt political conflict between court and parliament. The court's isolation reaches its most profound literary expression in the hermetically sealed pornographic fantasy of The Farce of Sodom (1684, attributed to the Earl of Rochester), whereas the acceptance of provisional solutions that characterises the urban and parliamentary mindset culminates in the worldmaking of Milton's Paradise Lost and Locke's Two Treatises of Government. The writings of mid- to late-period Dryden are particularly interesting in this respect because they attempt to mediate between these extremes. Dryden wants to preserve the old order in a new time, which is why he also attempts to overcome or at least conceal the divide between nature and politics.

In this way, nature and natural law are not only decisive foundations for seventeenth-century political thought but also a conceptual contexture of literary communication, in which ancient, especially stoic, patterns of thinking correlate with modern experiences, and new forms of a literary public sphere are created. Literary configurations of social life have to take up ever new positions in the conceptual space between nature and civitas. In doing so, writers need to develop appropriate media strategies for dealing with contingency between rhetoric, politics, and theatre, and between remembering and forgetting. 